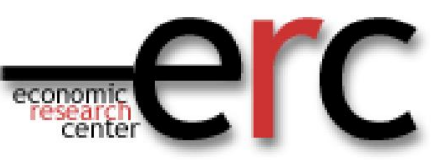

ERC Working Papers in Economics 09/02 October 2009

\title{
Brain Drain from Turkey: Return Intentions of Skilled Migrants
}

\author{
Nil Demet Güngör \\ Economics Department, Atılım University \\ Ankara 06836 Turkey \\ Phone: + 903125868605 \\ Fax: +903125868091 \\ E-mail: ndgungor@atilim.edu.tr \\ Aysit Tansel \\ Department of Economics \\ Middle East Technical University \\ Ankara 06531 Turkey \\ Email: atansel@metu.edu.tr \\ and \\ Institute for the Study of Labor (IZA) Bonn, Germany \\ Phone: +90 3122102057 \\ Fax: +903122107964 \\ E-mail: atansel@metu.edu.tr
}

\section{Economic Research Center}

Middle East Technical University

Ankara 06531 Turkey

www.erc.metu.edu.tr 


\title{
Brain Drain from Turkey: Return Intentions of Skilled Migrants ${ }^{1}$
}

\author{
Nil Demet Güngör \\ Economics Department, Atılim University \\ Ankara 06836 Turkey \\ Phone: + 903125868605 \\ Fax: +903125868091 \\ E-mail: ndgungor@atilim.edu.tr
}

\author{
Aysit Tansel $^{2}$ \\ Economics Department, Middle East Technical University \\ Ankara 06531 Turkey \\ and \\ Institute for the Study of Labor (IZA) Bonn, Germany \\ Phone: +90 3122102057 \\ Fax: +903122107964 \\ E-mail: atansel@metu.edu.tr
}

September, 2007

Revised: February 2, 2010

\begin{abstract}
The study estimates an empirical model of return intentions using a dataset compiled from an internet survey of Turkish professionals residing abroad. In the migration literature, wage differentials are often cited as an important factor explaining skilled migration. The findings of our study suggest, however, that non-pecuniary factors, such as the importance of family and social considerations, are also influential in the return or non-return decision of the highly educated. In addition, economic instability in Turkey, prior intensions to stay abroad and work experience in Turkey also increase non-return. Female respondents also appear less likely to return indicating a more selective migration process for females.
\end{abstract}

Keywords: skilled migration, brain drain, return intentions, Turkey JEL classification codes: F20, F22

\footnotetext{
${ }^{1}$ The study is based in part on the PhD thesis of Nil Demet Güngör (Güngör, 2003) supervised by Prof. Dr. Aysıt Tansel in the Economics Department of Middle East Technical University. Nil Demet Güngör thanks her examining committee members Hakan Ercan, Yusuf Ziya Özcan, Cem Somel, Fikret Şenses and Erinç Yeldan for their invaluable comments. The authors gratefully acknowledge the support of the Turkish Academy of Sciences Fellowship Program for doctoral studies and the financial support of the METU Research Fund, coded AFP-2000-4-03-06.

${ }^{2}$ Corresponding author.
} 


\title{
Brain Drain from Turkey: Return Intentions of Skilled Migrants
}

\begin{abstract}
The study estimates an empirical model of return intentions using a dataset compiled from an internet survey of Turkish professionals residing abroad. In the migration literature, wage differentials are often cited as an important factor explaining skilled migration. The findings of our study suggest, however, that non-pecuniary factors, such as the importance of family and social considerations, are also influential in the return or non-return decision of the highly educated. In addition, economic instability in Turkey, prior intensions to stay abroad and work experience in Turkey also increase non-return. Female respondents also appear less likely to return indicating a more selective migration process for females.
\end{abstract}

\section{Introduction}

An ever-growing number of studies deal with the various effects of skilled migration on the economies of the generally less developed sending countries. The earlier literature focused on the negative aspects of skilled migration. Hence the name "brain drain" was used to imply that a drain or depletion of skills and knowledge occurred from the developing countries to the developed countries at very little cost. In the 1960s and 1970s, the non-return of foreign students was a great concern in the economics literature. The classic articles in Adams (1968) emphasize the adverse effects on student non-return on home countries. Bhagwati and Partington (1976) suggested a special tax on non-returnees to be collected by the developed countries and remitted to the home countries. Later, the brain drain literature took a twist with the idea that a brain drain can be beneficial for the sending countries. Some researchers argued that a little brain drain (an optimal amount) can go some way in boosting the economic development of sending countries. A brief look at this recent and rapidly growing literature shows that the idea of a "brain gain" or a "beneficial brain drain" has taken on diverse perspectives. These studies highlight the potential benefits of skilled emigration and provide various theoretical outlooks for the ways in which a so-called "beneficial brain drain" can arise. Such studies argue for three possible channels for a brain gain. One is the flow of remittances to the home country. Second are the induced additional educational investments in the home country. Third is the possibility of knowledge and technology transfer through network effects. However, the empirical evidence on each of these possible effects is an 
unsettled issue. For instance, Faini (2006) provides evidence that skilled migrants remit less than unskilled ones, while a study based on microdata by Bollard et al. (2009) suggest the opposite.

Mountford (1997), as well as others (Stark et al. 1997, 1998; and Beine et al. 2001, 2003), claim that simply the perceived potential to emigrate abroad can provide an incentive for investing in human capital in the home country. Since emigration is not guaranteed, this is likened to an "emigration lottery" in which the winners emigrate and take their human capital with them (Kuhn and McAusland, 2006). Those who are unable to emigrate (the "losers"), however, contribute to the source economy by increasing the average level of human capital, since they have invested in human capital with the view of migrating abroad. Alternatively, in Kuhn and McAusland (2006)'s study, the public nature of knowledge is key to providing benefits to both the host and home countries. It is argued that emigrants produce higher quality knowledge in the host country due to the larger market size. This knowledge, because it is public and fully reproducible, is distributed back to the home country and the home country benefits. The relative importance of the benefits to the source country depends on a variety of factors including the strength of intellectual property rights in the two countries as well as the relevance of the knowledge created for the source country. Bucovetsky (2003), on the other hand, looks at how "brain drain" can reduce the incentive of the government to tax human capital, which in turn will have a beneficial effect on human capital formation and output growth in the home country.

Empirical evidence trying to demonstrate these effects has been mixed. Beine et al. (2003, 2008), using cross-country data find positive effect of skilled emigration on home country human capital investment for some countries. Faini (2003) and Schiff (2005), on the other hand, suggest that the beneficial effects may not materialize. Checchi et al. (2007) find that skilled emigration reduces home country investment in higher education. Brzozowski (2007) describes two channels through which the home country growth rate is reduced by brain drain in transitional countries. One is the direct effect of reduced human capital and the other occurs when individuals give up schooling with the prospect of migrating abroad. Glytsos (2009) finds that emigration of the skilled was harmful to the Albanian and Bulgarian economies and societies. Dessy and Rambeloma (2009) find that the impact of emigration on home country growth depends on the immigration policy of the host country. When it is skilled emigration, home country growth is negatively impacted despite remittances. When 
migrants are workers with low levels of human capital, the effect on the home country is positive.

Some of the beneficial brain drain theories emphasize the re-migration process - the possibility that migration may not be a once-and-for-all deal. Skilled migrants may go back and forth, and in the process help transfer knowledge and skills to their home country. This type of positive effect depends on the extent to which remigration occurs, and to the extent that when it does, whether it actually leads to a transfer of human capital (knowledge, skills and information) that will foster the development of the sending country. This depends on the "preparedness" of the returnee and the returnee's ability to "mobilize resources" (Cassarino, 2004). The diverse views taken by studies on the effects of skilled migration show that it is a complicated process that requires more than one perspective to understand. Haque (2005) argues that the issue of brain drain should be viewed and managed in much the same way as capital flight, where increased capital flight is viewed as an indicator of the need for policy correction. Kapur and McHale (2005: 177) also propose control of outflow of skilled migrants, as well as compensation, encouraging human capital at home and connection among countries.

Why do educated individuals migrate to other countries? In economic explanations of the brain drain, skilled migration is viewed as a response to the wage differentials that exist between the host and source countries. Wage differentials, however, offer only a partial explanation as to why skilled migration from developing countries to developed countries exists. A number of other "push" factors, such as unemployment, and economic and political instability in the home country, as well as "pull" factors, such as better career prospects and lifestyle freedom in the host country, may be important in the migration decision of skilled individuals. These are demand side factors that partially determine the brain drain. Supply side considerations are also important in explaining the volume of skilled migration. The retirement of "baby boomer" workers, for example, is one reason why many developed countries, such as Australia, Canada and the US, are now promoting the in-migration of highly skilled workers from abroad (Goberman and Shapiro, 2006). Goberman and Shapiro (2006) find that "pull" factors in relation to the economic conditions of the host country is more important in the migration decision of the highly skilled, while the "push" of economic factors in the home country is more important in the migration decisions of the less educated. However, other studies lead to opposite findings where economic conditions in the home 
country are relatively more important in migration decisions (Agarwal and Winkler, 1984 and 1985; Huang, 1987 and 1988). Bratsberg (1995) formulates a model of the non-return decision of foreign students in the United States. He finds that differences in economic and political conditions of the home countries are found to be important factors in explaining the variation in non-return rates across the home countries. In addition, students tend to return to rich and geographically close countries that place a high value on their investments in education (Bratsberg, 1995: 381).

Our study deals with return intentions and the factors that determine them, and is therefore limited to this particular aspect of the migration problem. It provides an econometric analysis of the determinants of the return intentions by making use of an original dataset obtained from a survey of Turkish scholars and professionals residing abroad. The information collected through the Internet survey is used to determine the empirical importance of various factors on the return intentions of the targeted population. Although the focus is on return intentions, some retrospective questions on the previous experience of survey participants also help to shed light on the effects of the remigration process (since some participants are re-migrants who have returned to Turkey and then went abroad again). There are indications that gross human capital transfer out of Turkey may be quite significant: Turkey ranks $24^{\text {th }}$ among the top sending countries according to UN sources. While the "brain drain" phenomenon is not a new one for Turkey, the media and policymakers in Turkey have turned greater attention to the loss of Turkey's educated workforce in the aftermath of the economic crises in November 2000 and February 2001, where a third of the educated workforce became unemployed (Işı̆̆ıçok, 2002).

This study provides quantitative evidence on the non-pecuniary factors in the return versus non-return decisions of Turkish professionals abroad. The main findings may be summarized as follows. The income differential is an important consideration for the majority of respondents. However, for this reason it fails to be a discerning factor in distinguishing between respondents with strong versus weak return intentions. The factor that exerts greatest positive impact on the probability of not returning is the initial intention to stay abroad. Family considerations, such as family support to settle abroad and marriage to a foreign spouse are found to exert a negative impact on return intentions. Longer stay duration, work experience and specialized training abroad are also found to negatively influence return intentions. Among various push factors, economic instability in Turkey has the greatest 
deterrent effect on return intentions. Those working in academe appear less likely to return. Another important finding is that female respondents are less inclined to return than male respondents, which may indicate a more selective migration process in the case of females. These results complement those of the descriptive study by Güngör and Tansel (2008b).

\section{Theoretical Perspectives on the Determinants of Non-Return}

In many cases, skilled migration is closely linked to study abroad. Non-returning students are an important part of the brain drain phenomenon ${ }^{1}$, and the United States is an important destination country for many foreign students. Foreign students make up approximately $4 \%$ of total enrollments in higher education institutions in the US (more than half a million in number), which is a substantial increase from $1.4 \%$ for the $1959-1960$ academic year (IIE, 2006). Many students choose to stay after completing their studies if they are able to obtain support from US firms. Statistics reveal that an increasing number of foreign students are not immediately returning to their home countries after completing their studies. Finn (2005)'s study shows that 67 percent of foreign students earning their $\mathrm{PhDs}$ in the science and engineering fields (in 1998) were still in the United States five years later in $2003^{2}$. The same five-year stay rate ten years earlier in 1993 was 58 percent. In general, stay rates are lower in the social sciences and highest in technical fields such as computer, electrical and electronic engineering and the physical sciences. Similar to the international experience, Table 1 also shows an initial increase in the five-year stay rates for the Turkish science/engineering $\mathrm{PhD}$ recipients in the US from 44 percent for the 1995 recipients to 50 percent for the 1996 recipients. The five-year stay rates have shown a gradual decline thereafter. The five-year stay rate was 49 percent in 2005, which fell to 42 percent in 2007. The overall five-year stay rate for international students in the US reached a peak of 68 percent in 2005 for the 2000 recipients. These indicate that although Turkish stay rates are

\footnotetext{
${ }^{1}$ International education does not always lead to a brain drain where international students work in skilled jobs abroad after completing their studies, but could instead "become a side door for low-wage labor importation" as in the case of Chinese students who work in low or semiskilled jobs in Japan due to labor shortages (Liu-Farrer, 2009: 180).
}

\footnotetext{
${ }^{2}$ This figure includes both students on temporary visas as well as students on permanent visas.
} 
somewhat lower than the international average, still almost half of the Turkish $\mathrm{PhD}$ recipients in the US choose to remain there. The table also provides the one-year stay rates, which are, in general, higher than the five-year stay rates. Although more than half of students stay for an additional year after completing their degrees, the stay rate declines in the years that follow. For instance, 53 percent of the 2002 recipients were in the US one-year later in 2003, while 42 percent of the same group was in the US five years later in 2007.

[Table 1 about here]

For Turkey, student non-return appears to be an important issue in addition to the emigration of skilled individuals. Previous studies on the Turkish brain drain also confirm student non-return to be an important phenomenon (Oğuzkan, 1971; Oğuzkan, 1975; Kurtuluş, 1999). A significant number of participants in our study have earned their highest degree in the foreign country they are currently working in, and are therefore part of the phenomenon of student non-return. Those who earned their highest degree in Turkey may be viewed as being part of the brain drain in the traditional sense: e.g., those who invest in human capital at home and then go abroad to work.

Several studies provide theories as to why student non-return may be a more important phenomenon than brain drain in the traditional sense. Employability in the home country may be a greater concern for those who receive their education abroad, since advanced education received through the foreign university system is believed to match the labour market needs of the host country more closely than the home country (Chen and $\mathrm{Su}, 1995)$. When foreign education is followed by work experience in the host country, the probability of return is expected to diminish further. Wong (1995) suggests that work experience abroad will enhance the productivity and earnings of migrants who tap into a greater "cumulative base of knowledge" in the host country through learning-by-doing.

Dustman (2001) views the migration and return decisions of individuals as being formed within a long term life cycle model of migration. Initial intentions about the length of stay in the host country play an important part in the education decisions made by migrants while abroad. Those who go abroad for longer stays tend to invest in host country specific human capital that may have little relevance for the home country. This tends to reinforce 
their initial intention to stay abroad. Those who plan a shorter stay abroad, on the other hand, accumulate less host country specific human capital and are therefore more likely to return.

\section{Methodology}

Many empirical studies of the brain drain rely on data obtained from questionnaire responses or face-to-face interviews. Some of these include studies on the Asian engineering brain drain (Niland, 1970), studies on China (Kao and Lee, 1973; Zweig and Changgui, 1995), and on Latin America (Cortés, 1980). The current study is based on a survey conducted by the authors during the first half of 2002, which resulted in over 1000 responses from Turkish professionals residing abroad. The survey methodology is described in detail in the Appendix A.1 of Güngör and Tansel (2008a). In the econometric analysis of return intentions described in this section, we set out to determine the factors that are significant in explaining the migration of university-educated workforce.

The dependent variable is the likelihood of returning to Turkey based on the response to the question "What are your current intentions about returning to Turkey?". Table 2 shows the possibilities presented to respondents. These choices form a set of ordered categories in which each consecutive category indicates an increase in intensity in the respondents' intentions to stay in their current country of residence. Because of the way the index is constructed, categories with a higher index value imply a greater intensity in feeling about not returning (staying). This means that positive coefficients on the independent variables indicate an increase in the probability of "not returning", while negative coefficients imply an increase in the probability of "returning".

[Table 2 about here]

However, the change in intensity between categories cannot be assumed to be uniform. Given the ordered and non-uniform nature of these choices, the appropriate model is an ordered response model (Maddala, 1983). Formally, the observed discrete index is given by

$$
y_{i}=\{1,2,3, \ldots, J\}
$$

where $i$ indexes the observations and $J$ is the number of categories of the dependent variable. It is assumed that a continuous, latent variable underlies the discrete, ordered categories. This 
latent variable is explained by a set of observed characteristics and a random element as given below:

$$
y_{i}^{*}=\beta^{\prime} X_{i}+u_{i}
$$

where $y^{*}$ is the unobserved "return intention" variable, $X$ is the $(k \times 1)$ vector of explanatory variables, $\beta$ is the parameter vector to be estimated and $u$ is the random disturbance term. The relationship between the discrete, observed $y$ and unobserved, continuous $y^{*}$ is given as follows:

$$
y_{i}=\left\{\begin{array}{l}
1 \text { if } y_{i}^{*} \leq 0\left(=\mu_{1}\right) \\
2 \text { if } 0<y_{i}^{*} \leq \mu_{2} \\
3 \text { if } \mu_{2}<y_{i}^{*} \leq \mu_{3} \\
4 \text { if } \mu_{3}<y_{i}^{*} \leq \mu_{4} \\
\cdots \\
J \text { if } \mu_{J-1} \leq y_{i}^{*}
\end{array}\right.
$$

where $\mu_{1}, \mu_{2}, \mu_{3} \ldots \mu_{J-1}$ are the threshold parameters linking $y$ to $y^{*}$, which are estimated along with the explanatory variable coefficients. The ordered probit specification, which assumes an underlying normal distribution for the error term, is used in this study to estimate the return intentions model. Given an ordered probit specification, the probability that an observed response falls into an arbitrary category $j$ is given below as:

$$
\operatorname{Prob}\left(y_{i}=j\right)=\Phi\left(\mu_{j}-\beta^{\prime} x_{i}\right)-\Phi\left(\mu_{j-1}-\beta^{\prime} x_{i}\right)
$$

where $\Phi($.$) is the cumulative normal distribution. Differentiating this probability with respect$ to the explanatory variables gives the marginal effect of each on the probability of choosing category $j$. Model estimation is carried out by using maximum likelihood (ML) estimation techniques since it has been shown that ML gives unbiased and efficient estimates for nonlinear models. Please refer to Appendix A.2 of Güngör and Tansel (2008a) for further details of choice of estimation methodology.

\section{Determinants of Return Intentions}

As given in detail in the previous section, the estimated econometric model is an ordered probit model where the dependent variable is an ordinal variable measuring the intensity of return intentions. Table 3 provides the ordered probit results for the final econometric model. The table also includes summary statistics and descriptions of the variables used. The final model was chosen on the basis of goodness-of-fit statistics: mainly 
the AIC and McFadden's adjusted $\mathrm{R}^{2}$. In comparing nested models, the likelihood ratio test was also used. In general, these three statistics give very similar results. The final model has 59 regressors, many of which are qualitative or dummy variables, as well as interaction variables. The marginal effects of selected discrete and continuous variables are provided in Table 4 and Table 5 respectively.

1. Gender Effects $\left(X_{\underline{1}}\right)$ : There are very few studies that address the gender dimension of the brain drain. Dumont et al. (2007) and Docquier et al. (2007) are examples of recent studies that look at this issue. Docquier et al. (2007) find that women exhibit higher rates of brain drain than men in the OECD countries. Women's brain drain is $17 \%$ above men's, on average. The five countries sending the largest stock of migrants to the OECD in 2000 are Mexico, UK, Italy, Germany and Turkey. The share of women in total skilled migration from Turkey to the OECD is $36.5 \%$.

We therefore expect significant gender differences in the estimated probabilities of return intentions for our sample. A positive, statistically significant coefficient on the gender dummy variable $\left(\mathrm{X}_{1}\right)$, which takes on the value 1 for "female" and 0 for "male", indicates that female respondents have a higher probability of having "non-return" intentions. The marginal effects (see Table 4) are computed by holding all other explanatory variables at their means and accounting for gender interaction effects ${ }^{3}$. The gender differences in the marginal effects show a clear tendency for females to indicate plans to remain abroad compared to males. The probability of returning to Turkey being unlikely $(\mathrm{y}=4)$ is 0.10 points higher for female respondents, and the probability of definitely returning ( $y=1$ or 2 ) decreases by 0.07 . This may be because educational and migration opportunities for women are more limited, which makes the migration of females a more selective process (e.g., as evidenced by the higher socio-economic background of females in the survey as measured by the parents' education levels). Another important factor may be the greater freedom of lifestyle that some of them may enjoy while abroad. This is in line with previous studies that have found women to be less inclined to return to their homelands (see, for example, Zweig and Changgui (1995) for

\footnotetext{
${ }^{3}$ For example, because there are gender differences in the relative importance placed on economic instability as a push factor, the interaction variable (FEMALE) $\mathrm{x}\left(\mathrm{X}_{40}\right)$ is set to zero for males and to (1) $\mathrm{x}\left(\right.$ mean of $\left.\mathrm{X}_{40}\right)$ for females, where $\mathrm{X}_{40}$ is the dummy variable for economic instability as a push factor.
} 
the case of China) because of the lack of career prospects and lifestyle constraints in addition to the opportunity to earn a better wage. According to one survey respondent:

I had all the intentions of returning at the end of my $\mathrm{PhD}$. When I left Turkey I was 24 and had been married for three years. Toward the end of my $\mathrm{PhD}$ I got a divorce at the age of 26. In 1986, Turkey was not ready to accept the notion of a 26 year old divorced woman living by herself. My family expected me to live with them. That was not acceptable to me. Even today I do not feel that I would be as comfortable (or receive the same amount of respect I get in the USA) living in Turkey as a divorced 42 year old.

2. Age Effects $\left(X_{2}, X_{3}\right):$ We include age $\left(\mathrm{X}_{2}\right)$ and the square of age $\left(\mathrm{X}_{3}\right)$ as explanatory variables in order to control for cohort effects and possible nonlinearities. Previous empirical research has established age as an important factor in determining the net present value of migration. Older workers tend to be less mobile than younger workers since the "psychic costs" of moving increase with age (Stark and Bloom, 1985). Older participants may therefore be expected to indicate a greater intention of remaining in the host country. However, those approaching retirement may be expected to exhibit stronger return intentions than younger participants who face a longer time frame for working and earning a high salary level in the foreign country.

The two age variables are statistically significant at the $1 \%$ significance level for the ordered probit model when the stay duration and work experience variables are excluded. A positive sign on the age coefficient indicates a higher intensity in non-return intentions for older respondents. This may be a reflection of the possibility that older respondents have spent more time abroad than younger respondents and are more firmly established in their overseas careers and/or have become more accustomed to the lifestyle abroad. As such, AGE $\left(\mathrm{X}_{2}\right)$ may be correlated with the STAYDURATION variable $\left(\mathrm{X}_{4}\right)$. Older individuals also tend to be less mobile than younger individuals, and therefore may exhibit a greater tendency ("inertia") to stay in their current place of residence. A negative sign on the squared age variable $\left(\mathrm{X}_{3}\right)$ means that the tendency for individuals to "not return" increases with age at a diminishing rate. When stay duration, years of work experience and possible interaction effects (e.g., AGExSTAYDURATION and AGESQxSTAYDURATION) are controlled for, the coefficients become marginally statistically insignificant. 
3. Stay Duration $\left(X_{4}\right)$ : Stay duration is the number of years spent abroad. The probability of returning to Turkey is expected to decrease as stay duration increases, holding everything else constant (including age and work experience). Stay duration may be thought of as reflecting "inertial effects", where returning becomes difficult after individuals become accustomed to living conditions abroad. Increases in the length of stay may speed up the acculturation process and shift personal lifestyle preferences in favor of the culture of the host country. "Psychic" or adjustment costs associated with the initial move to a foreign country diminish as the length of stay increases, while the "psychic" costs involved in returning to Turkey may increase substantially. Some respondents indicate that the social changes that take place in Turkey occur at a very rapid pace, which suggest that adjustment costs to returning can rise substantially as the length of stay abroad increases. In addition, being away from Turkey also means being away from social and career networks that are important in finding a job. This also becomes more difficult when the length of stay abroad increases. Our results indicate that return intentions indeed become weaker with the number of years spent abroad (this is statistically significant at the 1 percent significance level).

Figure 1 and Figure 2 show the marginal effects of stay duration on return intentions holding age constant at 35 years, which is close to the average age for the sample. The marginal effects for the extreme categories "definite return plans" (DRP) and "definitely not return" (DNR) are small and lie close to the origin as illustrated in Figure 1, although definite return plans show a decrease in probability as stay duration increases, while the probability of definitely not returning shows a rise. The overall trend is an increase in the probability of not returning and a decrease in the probability of returning as stay duration increases, which is as expected ${ }^{4}$.

[Figure 1 about here] [Figure 2 about here]

\footnotetext{
${ }^{4}$ Similarly, Gökbayrak (2009) finds that the return tendency gets weaker as stay duration increases for Turkish engineers working abroad. Other findings by Gökbayrak, in general, complement this study and the findings of Tansel and Güngör (2003) and Güngör and Tansel (2008a; 2008b).
} 
4. Initial Intentions $\left(X_{5}, X_{6}\right)$ : Initial intentions reflect the return intentions of respondents at the beginning of their stay abroad. Initial intentions are believed to affect migrants' behaviour abroad. For example, those who intend to stay for longer periods are expected to invest in human capital that is more specific to the host country and less relevant for the home country (Dustman, 2001). The reverse is true for those with shorter stay plans, and this tends to reinforce migrants' initial plans. Thus, it is expected that respondents who expressed an initial intention to return will be more likely to have similar intentions at the time of filling out the survey. Initial return intentions are given by a set of dummy variables representing the categories: "return", "undecided" and "stay". The dummy variables $\mathrm{X}_{5}$ ("undecided") and $\mathrm{X}_{6}$ ("return") are included in the model, and "stay" is chosen as the reference category.

Both the "return" and "undecided" variables are negative and significant at the $1 \%$ significant level. The probability of definitely returning $(y=1,2)$ increases by 0.22 for respondents with an initial intention to return compared to those with an initial intention of staying abroad. The increase in the probability of definitely returning is lower $(0.10)$ when the comparison group is those who are initially unsure about returning. The probability of being unlikely to return is quite high (0.63) for those whose initial intention is to stay in the host country. The probabilities of definitely not returning and of return being unlikely increases by 0.09 and 0.40 respectively, when respondents have initial "stay" intentions compared to those with initial return intentions. These figures suggest that the initial or prior intentions of individuals tend to shape their current intentions about whether to return to Turkey or not. This tendency, however, appears to be strongest for those with initial plans to remain abroad. These results may be reflecting the "self-fulfilling" tendency of prior intentions and expectations: e.g., those who start out more determined from the outset to make a career or succeed abroad will try harder to make this come true; they may also tend to try to protect themselves psychologically from setbacks or initial adjustment problems, and exhibit greater tolerance when they occur.

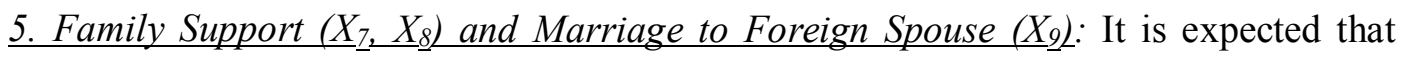
family constraints will be important in the migration decisions of skilled individuals. Respondents were asked about the degree of support (encouragement) that they received from their families (parents, wife, and children) in the initial decision to work or study abroad $\left(\mathrm{X}_{7}\right)$ and in the decision to settle overseas permanently $\left(\mathrm{X}_{8}\right)$. Both of the family support variables 
are ordinal categorical variables that are treated as interval variables in the econometric model. This decision is based on whether the null hypothesis of evenly spaced categories is rejected by a likelihood ratio (LR) test ${ }^{5}$.

Family support for the initial decision $\left(\mathrm{X}_{7}\right)$ is negative and significant (at the 1 percent significance level). This means that the probability of returning increases when there is support for the initial decision to go abroad. It is clear that there is strong family support for the initial decision to acquire overseas study or work experience for a majority of respondents: the families of three-fifths of respondents were "very supportive". This variable may be indicative of the strength of ties to family in Turkey, which offers a possible explanation of the negative sign on the coefficient and higher probability of return.

The second "family support" variable is a measure of how much encouragement the respondent believes that she/he would receive from her/his family for the decision to settle abroad permanently $\left(\mathrm{X}_{8}\right)$. Less than a third of participants believe their family would be "very supportive" in this decision. The interpretation of the positive and statistically significant coefficient (at the 1 percent significance level) in the ordered probit model for this variable is more clear-cut. Respondents with greater family encouragement in the decision to settle abroad permanently have a greater probability of not returning to Turkey. This outcome appears to validate the importance of family encouragement in the decision to migrate, especially for individuals coming from a traditional, family-oriented society such as Turkey.

Another important consideration is marriage to a foreign spouse, represented by the dummy variable $\mathrm{X}_{9}$, which is expected to decrease the likelihood of returning. The sign of the

\footnotetext{
${ }^{5}$ Maximum likelihood testing procedures were performed to determine whether the ordered family support categories could be treated as interval. To illustrate, in performing the LR test, the model containing the ordinal variable $\mathrm{X}_{7}$ is compared to the model that includes both $\mathrm{X}_{7}$ and all but two of the categories of $\mathrm{X}_{7}$. If the restricted model leads to a loss in information, then the ordinal variable cannot be treated as an interval variable (see Long and Freese, 2001: 268-9). Test results:

$\mathrm{X}_{7}$ (ordered probit model): $\operatorname{LR} \chi^{2}(2)=5.16$, Prob $>\chi^{2}=0.0757$;

$\mathrm{X}_{8}$ (ordered probit model): $\operatorname{LR} \chi^{2}(4)=5.48$, Prob $>\chi^{2}=0.2414$;
} 
coefficient on this variable is negative and statistically significant at the 1 percent significance level, indicating a lower intention of returning when a respondent is married to a foreign spouse as expected. Family support for permanent settlement and marriage to a foreign spouse decrease the probability of definitely returning by $0.037(=0.0016+0.0362)$ (Table 5) and $0.085(=0.0030+0.0823)($ Table 4$)$ respectively. Initial family support for overseas study or work, on the other hand, tends to increase definite return intentions by $0.042(=0.0019+$ 0.0413) (Table 5). As expected, marriage to a foreign spouse has a very large positive effect of $0.15(=0.1383+0.0145)$ (Table 4$)$ on the probability of "being unlikely to return", which is much larger than the effect of family support for settlement abroad $(0.056=0.0520+$ 0.0039) (Table 5).

6. Characteristics of the Highest Degree $\left(X_{10}, X_{11}, X_{12}\right):$ It is expected that higher levels of formal education received abroad, corresponding to a greater degree of country or institution-specific specialization, will result in a lower tendency for returning to Turkey. Each consecutive level of higher education represents an increasing degree of specialization. It is postulated that those who have received more specialized formal education abroad, based on the degree level, are less likely to return since their advanced training will be more relevant or attuned to the needs of the foreign country, which in turn will provide them with higher monetary returns in the host country than in their native country. In addition, if the highest degree completed by a respondent is from a Turkish institution of higher education, then the individual is part of the "classic brain drain". On the other hand, if the highest degree completed is from an educational institution outside Turkey, then the respondent may be considered part of the phenomenon of "student non-return".

While the highest degree held by the respondent had no significant effect on the return intentions of respondents in our estimated model, where the highest degree is received did turn out to be important. Those who have received their highest degree from a Turkish university $\left(\mathrm{X}_{10}\right)$ are more likely to indicate they will return than those whose highest degree is a foreign degree. This is statistically significant at the $1 \%$ significance level. This also means that higher education received abroad, regardless of the level, is important in the decision to 
return or stay ${ }^{6}$. This result is an indication that student non-return is a potentially more serious problem for Turkey.

According to Chen and $\mathrm{Su}$ (1995), students in capital-intensive fields (where a complementary relationship exists between the education received and the physical and social capital stock of the host country) will be less likely to return than students in non capitalintensive fields (such as law, sociology and the like). To test this, the highest degree fields were arranged into three groups: architecture, economics and administrative sciences (which is the base or reference category); education, languages, sociology and arts $\left(\mathrm{X}_{11}\right)$; and engineering, mathematics, science and medicine $\left(\mathrm{X}_{12}\right)$. In the ordered probit analysis, the coefficients on these variables are both positive and statistically significant at the $1 \%$ significance level. We find that those in the "hard sciences" or more capital intensive fields, as defined by $\mathrm{Chen}$ and $\mathrm{Su}$, are more likely to stay abroad compared to those in education, language, and so on. However, in contrast, in this paper the least likely to return are those who hold their highest degrees in architecture, economics or administrative sciences. Economic instability and the crisis environment in Turkey, which has had important repercussions in the banking and finance sectors during the 2001 crisis, may offer a partial explanation for this.

7. Number of Years of Work Experience Abroad $\left(X_{13}\right)$ : Wong's (1995) model of brain drain based on learning-by-doing interprets the greater output level in the host country as representing a cumulative base of experience. Foreign workers choosing to stay in the host country are able to take advantage of the greater base of experience and increase their productivities from learning-by-doing. The number of years of work experience $\left(\mathrm{X}_{13}\right)$ in the host country is believed to contribute to the host country-specific general skills level of the migrant. Thus, it serves as a proxy for the amount of learning-by-doing accumulated in the host country. Return intentions are expected to decline as the number of years spent working abroad increases. If this is the case, Wong's learning by doing model will receive confirmation.

\footnotetext{
${ }^{6}$ The analysis was also done with the following dummies: 1) highest degree is from Turkey; 2) highest degree is a foreign bachelors degree; 3) highest degree is a foreign master's degree; 4) highest degree is a foreign doctoral degree. These variables are not included in the formulation presented in Table 3.
} 
This model can be tested by including the variable "number of years of overseas work experience" in the model (or the number of years of experience in current country of residence). Goss and Paul (1986), argue that when the number of years of work experience is not controlled for, the coefficient on the "age" variable will be the sum of two countervailing factors. If the distinction between work experience in the home country versus in the foreign country is important for return intentions, then the number of years of work experience abroad may be the more pertinent variable (Wong, 1995), since this implies that respondents with greater overseas work experience will have acquired skills that are related to the capital stock of the host countries.

According to Wong's model, the greater the amount of work experience gained abroad the less likely it will be to have return plans. Indeed, this is the case. The coefficient on the work experience variable is positive and statistically significant at the 1 percent significance level. Figure 3 shows the marginal effects of different amounts of work experience on return intentions. The same qualitative results apply as for the stay duration variable, except that increases in work experience appear to have a stronger negative effect on return intentions than do increases in stay duration (see Figure 3 ). The probability of not returning ( $y=4$ or 5 ) increases by 0.07 for the first five years of work experience, and then by 0.09 for the second five years, and finally by 0.10 for the next five years after that. By comparison, the same figures for stay duration are $0.03,0.04$ and 0.05 respectively. The negative impact of foreign work experience on return intentions provides empirical support for Wong's learning-bydoing model of brain drain.

[Figure 3 about here]

8. Previous Overseas Experience $\left(X_{14}, X_{15}\right)$ : Prior overseas experience (work, study or travel) before coming to the current country of residence may be an influential factor in adjusting to or feeling comfortable with the current country of stay. Some of those with previous overseas experience who returned to Turkey to work for a period of time have also had the opportunity to compare the work environments and therefore base their return decisions on this comparison. In addition to prior experience overseas, various adjustment factors were included in the questionnaire, including having a large Turkish community in the city of residence. These factors and difficulties faced while abroad are included in the model as dummy variables. 
Whether a respondent has had any work experience in Turkey appears to be an important determinant of current return intentions, in addition to the amount of work experience obtained in the host country. When a respondent has no full-time job experience in Turkey $\left(\mathrm{X}_{14}\right.$ takes on the value of one), the probability of not returning ( $\mathrm{y}=4$ or 5$)$ increases by 0.08 , and is slightly higher for females. Previous examination of the data using correspondence analysis (Güngör, 2003; Tansel and Güngör, 2008b) suggested the possibility that respondents who returned to Turkey to work after obtaining foreign degrees are less likely to return a second time. The dummy variable $X_{15}$ takes on a value of 1 for respondents completing their highest degree abroad if their first full-time job after completing their studies is located in Turkey. The probability of not returning ( $y=4$ or 5$)$ increases by 0.18 , while the more positive return intention categories- "definitely return, no plans" (DRNP: y $=2$ ) and "return probable" (RP: $y=3$ ) - decrease in total by about the same amount. The probability of choosing the "definitely return, no plans" category decreases by 0.10 for male respondents compared to a decline of 0.07 for females, and the probability of "probably returning" (RP) decreases by 0.11 for female respondents versus a decline of 0.07 for males.

These results (e.g., the negative impact of work experience in Turkey for respondents with foreign degrees and the phenomenon of student non-return) have important implications for the "brain circulation" hypothesis, which is pervasive in the current literature on the impact of migratory flows. It appears that respondents who start their work life abroad after completing their overseas studies are less likely to have strong return intentions, and respondents with foreign degrees who start their work life in Turkey are less likely to have plans for returning to Turkey again ${ }^{7}$.

9. Formal Training Abroad Specific to Organization ( $\left.X_{16}\right)$ : One of the main arguments set forth by Chen and Su (1995) to explain the phenomenon of student non-return is on-the-

\footnotetext{
${ }^{7}$ Toward the end of the survey questionnaire respondents were asked about the frequency of their visits to Turkey for various purposes, including for educational and work endeavours. Unfortunately, this part of the survey had a low response rate and could not be used to determine the degree to which productive brain circulation is occurring on behalf of Turkey.
} 
job training. Training received on the job abroad after completing overseas studies is expected to instill skills that are given a higher premium in the country in which they are received. This wage differential, in turn, is supposed to favor the host country and keep foreign workers abroad. To test on-the-job training as a cause of brain drain directly, respondents were asked whether they have received informal on-the-job training at their current overseas jobs. Nearly $60 \%$ of respondents have received some on-the-job training, and for $10 \%$, this training is specific to the organization and cannot be easily transferred to other organizations.

The following dummy variables were constructed: "did not receive on-the-job training", "received general on-the-job training", "received on-the-job training specific to industry, and "received on-the-job training specific to organization". With "no on-the-job training" as the reference category, the coefficients of the "general" and "specific to industry" were positive with expected signs but not statistically significant. This indicates that on-the-job training does not have explanatory power for differences in return intentions. These variables were, therefore, not included in the final model. On the other hand, formal training specific to the organization (represented by $\mathrm{X}_{16}$ ) is positive and statistically significant at the $10 \%$ level indicating that respondents who have gone through formal specialized training are less likely to return. The probability of not returning to Turkey ( $y=4$ or 5$)$ increases by 0.14 while the probability of definitely returning $(y=1$ or 2$)$ falls by 0.08 . Firm-specific training as a cause of brain drain is limited to a very small proportion (3.8\%) of participants in the sample.

$\mathrm{R} \& \mathrm{D}$ activities are given a greater premium in advanced countries compared to the developing countries. Those engaged in $R \& D$ are therefore expected to be less willing to return. In the sample, about $40 \%$ of those engaged in research and development activities are academicians $(166 / 421 * 100)$. The R\&D dummy variable was not significant at any conventional significance level. This is not an expected result since the problem here may be how respondents interpreted the different job activities ${ }^{8}$.

\footnotetext{
${ }^{8}$ The respondents were also asked if they had any patented inventions. A dummy variable 'patent' was constructed $(1=$ 'has patent'; $0=$ 'does not have patent') to determine whether return intentions for individuals with patents differed from those without. The coefficient for this variable was not statistically significant.
} 
10. Academic vs. Non-Academic Professions ( $X_{17}$ ): A distinction can be made between academic and non-academic occupations. A dummy variable representing working in academia was constructed to determine whether academicians are more or less likely to return than those in other occupations. Respondents were also asked to give the percentage of time they spend on various job-related activities. The first three job activities (basic research, applied research and development) are R\&D activities (OECD, 1994). The other activities considered are technical support, administrative and various other activities. These activities have been used as part of the National Science Foundation (NSF) Survey of Doctorate Recipients in the US (NSF, 1997). If respondents devoted at least half their time on R\&D activities, they are labeled as R\&D workers and placed in the R\&D category. A dummy variable, R\&D ( 1 if $R \& D$ worker, 0 otherwise), is used to represent the effect of being involved in research and development activities overseas. It is expected that respondents involved in activities related to research and development will have weaker return intentions, since they are doing very specialized work that may be difficult to duplicate or develop in Turkey.

In the analysis, "academic" refers to individuals who are teaching and/or doing research at a 4-year university or at research centers and medical schools affiliated with a 4-year university. Academicians make up $30 \%$ of the overseas labor force sample. A dummy variable, $X_{17}$, ( 1 for academic, 0 for non-academic professions) is used to determine whether the return intentions of the academicians in the sample differ from the non-academic labor force. This variable is not found to be statistically significant, although it is an important modifier or interaction variable in the analysis of push and pull factors given below.

\section{Effect of Social Life and Standard of Living Assessment $\left(X_{18^{1}}, X_{19}\right)$ : Respondents} were also asked to assess in general terms their personal work environment (e.g., job satisfaction), the social aspects of life (e.g., friendships, social relations) and standard of living in their current country of residence versus that in Turkey on a 5-point scale ranging from "much worse" to "much better". Work and standard of living assessments are skewed toward the "better" or "much better" categories. These two variables also turn out to be positively associated with lifestyle preferences. The distribution of the social assessment variable appears not to be as slanted toward extreme points, although it is tilted toward the "worse" categories. The work assessment variable was not statistically significant and was 
therefore excluded from the model ${ }^{9}$. The coefficients on the social life assessment $\left(\mathrm{X}_{18}\right)$ and standard of living assessment $\left(\mathrm{X}_{19}\right)^{10}$ variables are positive and statistically significant at the 5 percent and 1 percent significance levels respectively, indicating a decrease in return intentions when more positive assessments are made about conditions abroad compared to Turkey.

It is clear that positive assessments of living conditions abroad lead to greater decreases in the probability of indicating return intentions than do positive assessment about social conditions abroad. Figures 4 and 5 give the cumulative probabilities associated with each value ( 1 to 5 ) that the social assessment and standard of living assessment variables take on. Areas toward the bottom represent more definite plans and areas at the top represent more definite non-return intentions. These diagrams also show that standard of living assessments have a greater impact on return intentions than assessments made about social environment.

[Figure 4 about here] [Figure 5 about here]

12. Initial Reasons for Going $\left(X_{20}-X_{25}\right)$ : Since initial return intentions appear to be important in determining current return intentions, the initial reasons for going overseas may also provide important information about who is planning to return and who is not. Only six of the possible twelve reasons presented to the respondents are found to have statistical significance. They are the ones included in the final model. Some of these factors become significant only when their interactions with certain variables such as age, female and academic are controlled for.

\footnotetext{
${ }^{9}$ Wald test of significance: $\chi^{2}(1)=0.12$, Prob $>\chi^{2}=0.7321$.
}

${ }^{10}$ The likelihood ratio test results for whether the ordinal variables can be treated as interval are as follows:

$\mathrm{X}_{18}$ (social assessment): $\operatorname{LR} \chi^{2}(4)=2.95$, Prob $>\chi^{2}=0.5663$;

$\mathrm{X}_{19}$ (standard of living assessment): LR $\chi^{2}(4)=11.58$, Prob $>\chi^{2}=0.0207$.

The likelihood ratio test results indicate that $\mathrm{X}_{18}$ can be used at the interval level, but treating $\mathrm{X}_{19}$ as an interval variable leads to loss of information. Despite this, both variables were included as interval variables in order to keep the model simple. This did not lead to a change in the qualitative results. 
The results from the estimated ordered probit model indicate that respondents are more likely to return if their initial reason for going was any of the following: having a job requirement in Turkey $\left(\mathrm{X}_{20}\right)$, prestige of overseas study $\left(\mathrm{X}_{21}\right)$, or to join spouse $\left(\mathrm{X}_{22}\right)$. The first two are statistically significant at the $10 \%$ and the last at the $1 \%$ significance level. A positive, significant coefficient at the 10 percent level for the interaction terms $\left(\mathrm{F} \mathrm{x} \mathrm{X}_{24}\right)^{11}$ and $(\mathrm{F} \mathrm{x} \mathrm{X} 20)^{12}$ indicates that these results hold for males. Male respondents are more likely to return if they initially went abroad as a requirement or to be with their spouses. The result for $\mathrm{X}_{22}$ (the prestige of overseas study), on the other hand, is moderated by age (through a positive and significant coefficient of the term $\mathrm{AGExX}_{22}$ at the $10 \%$ significance level) and strengthened if the respondent is working in academia (through a negative and significant coefficient of the term $\mathrm{ACADEMICxX}_{22}$ at the $5 \%$ significance level).

As expected, respondents who left Turkey because of lifestyle preferences $\left(\mathrm{X}_{23}\right)$ or due to political factors $\left(\mathrm{X}_{25}\right)$ are not likely to indicate strong return plans. The coefficients of these variables are positive and statistically significant at the 5\% and $10 \%$ significance levels respectively. Respondents who left because they found facilities and equipment for doing research in Turkey to be inadequate $\left(\mathrm{X}_{21}\right)$ are also less likely to be returning (significant at $1 \%)$.

Lifestyle preference has the greatest negative marginal effect on return intentions, followed by getting away from the political environment and insufficient facilities for conducting research in Turkey. The probability of not returning ( $y=4$ or 5 ) increases by 0.07

\footnotetext{
${ }^{11}$ The in-sample bivariate association between return intentions and $\mathrm{X}_{20}$ as measured by the chi-square statistic $\chi^{2}(4)$ is $1.84(\operatorname{Pr}=0.76)$ for females and $8.68(\operatorname{Pr}=0.07)$ for males, even though a greater percentage of female respondents have indicated that their reason for going abroad is to be with their spouses $(23.1 \%$ versus $8.2 \%)$.

${ }^{12}$ The percentage of females in the sample whose initial reason for going abroad was to fulfil a job requirement in Turkey is approximately the same as that for males $(21.7 \%$ versus $22.6 \%)$. Interestingly, the chi-square statistic between return intentions and $\mathrm{X}_{20}$ is significant only for males $\left(\chi^{2}(4)=41.57, \operatorname{Pr}=0.00\right)$, and there is a clear tendency (based on an examination of table percentages) for males who chose $\mathrm{X}_{20}$ as their reason for going abroad to have stronger return inclination than those who did not.
} 
for those who have indicated lifestyle preference to be their reason for going abroad, compared to 0.05 for political reasons and 0.03 for insufficient facilities. Respondents who indicated they went abroad to be with their spouse have the highest return intentions: the probability of choosing one of the "definitely return" categories increases by 0.096 (0.0054+0.0905), compared to 0.024 for those who went because of a job requirement in Turkey and 0.017 for those who went abroad to take advantage of study opportunities.

\section{Difficulties Faced Abroad and Adjustment Factors $\left(X_{26} \underline{-} \underline{X}_{28}\right)$ : The main difficulty} with life abroad that was statistically significant at the 10 percent level in the empirical analysis is that of missing one's family in Turkey $\left(\mathrm{X}_{28}\right)$. The probability of returning $(\mathrm{y}=1$ or 2) increases by 0.05 for those who indicate that missing family is one of the difficulties they have faces while abroad. "Missing family" was an important difficulty for a great proportion of respondents in the sample (83\%). Previous experience and involvement in a Turkish student association also have a similar, but slightly greater impact on return intentions. The greater return intentions associated with these adjustment factors may be due to the fact that respondents who indicate they have had difficulties abroad also have to adjust compared to those who indicate they had no difficulties and therefore did not need to adjust.

14. Contributions to Turkey $\left(X_{29}\right)$ : Those who make contributions to Turkey during their stay abroad are also more likely to indicate they will return. This is included in the model as the dummy variable, $\mathrm{X}_{29}$, which takes on a value of 1 when respondents have contributed either by making donations, taking part in lobbying activities or by participating in activities such as attending conferences in Turkey. The effect of this on the likelihood of returning is substantial: the probability of definitely returning increases by 0.09 . This suggests perhaps that those who are already likely to return are also those contributing the most to Turkey through various activities.

15. Effects of Various Push and Pull Factors $\left(X_{30} \underline{-} \underline{X}_{33}\right.$ and $\left.X_{34}-\underline{X}_{41}\right):$ : Given the importance of perceptions in making the migration decision, a set of "subjective" variables are used to determine the significance of various economic and social factors. These include the respondents' rankings of various push-pull factors in terms of their importance in their intention to return or stay. 
According to human capital theory, the difference in the expected foreign and domestic income levels is the key determinant of skilled migration. To account for the pecuniary aspect of the migration decision, "lack of a satisfactory income level in the home country" was included among the push factors and a "competitive income level in the current country of residence" was included as a pull factor. They are not, however, included in the final model. The approach of using these two subjective measures to test the impact of income differences may be justified by the fact that each migrant may have different perceptions of the income differential based on incomplete information of all alternative employment opportunities available to him or her. Not everyone may be equally informed of the prevailing income differentials, and more importantly, they may not place equal weight or importance to the same information. Another difficulty in using actual income differences is that it would require income information for a diverse range of occupations, and comparisons across countries would also need to take into account cost-of-living differences.

Since expected income is the relevant variable, employment opportunities and labor market conditions both at home and abroad may play an important role in the perceptions of economic opportunity held by skilled individuals. General economic conditions and economic stability will determine relative employment opportunities and can lower or increase an individual's expected income accordingly. Economic instability and uncertainty in the home country $\left(\mathrm{X}_{33}\right)$ was included among the Likert scale items as a push factor. This variable is expected to have a strong deterring effect on return intentions for the sample considered since at the time of the survey the Turkish economy was experiencing the effects of the 2001 economic crisis.

The examination of local economic conditions in the home country (push factors) and in the host country (pull factors) provides a framework for understanding the migration of highly skilled individuals. Globerman and Shapiro (2006), in general, find that "pull" factors tend to be more important in the migration decisions of the highly skilled, while "push" factors are more prominent in the migration of the less educated. Economic conditions, such as income differentials between the host and home countries, are frequently cited as among the most important reasons for the brain drain. Many elaborate models of the brain drain found in the literature are based on explaining how this income differential occurs. 
We use a relatively simple test of whether income differentials are important. To determine whether income differentials are important, we include a dummy variable that takes on the value 1 when a respondent indicates that a higher salary or wage is a "very important" or "important" reason for not returning or postponing returning to Turkey on a 5-point Likert scale. The disadvantage of this construct is that it is a subjective measure, although it can be argued that the migration decision is based on the perceptions of a wage differential. The income variable is found to be statistically insignificant and is therefore excluded from the final model of return intentions.

Of the twelve "push" factors presented to participants, only four were found to be statistically significant: limited job opportunity in specialty at home $\left(\mathrm{X}_{30}\right)$, little opportunity for advanced training at home $\left(\mathrm{X}_{31}\right)$, lack of financial resources for business ventures at home $\left(\mathrm{X}_{32}\right)$ and economic instability and uncertainty at home $\left(\mathrm{X}_{33}\right)$. Having limited job opportunities in specialization decreases the probability of returning, but this carries greater significance for those in academia or research-oriented institutions ${ }^{13}$. Return intentions decrease with age, as we have seen. This effect is magnified when respondents indicate that there is very little opportunity for advanced training in Turkey ${ }^{14}$. Respondents who viewed the lack of financial resources for business ventures in Turkey $\left(\mathrm{X}_{32}\right)$ as an important push factor are more likely to be returning than those who did not. The coefficient on this variable is negative and significant at the $10 \%$ significance level. Economic instability and uncertainty $\left(\mathrm{X}_{33}\right)$, on the other hand, appears to have a strong negative effect on return intentions which is statistically significant at $1 \%$.

The marginal effects on each of the significant push factors are presented in Table 4 . It is clear that the greatest negative effect on return intentions is due to economic instability and uncertainty: the probability of not returning $(y=4$ or 5$)$ increases by 0.12 for those indicating

\footnotetext{
${ }^{13}$ The coefficient of the interaction dummy variable (ACADEMIC) $\mathrm{x}\left(\mathrm{X}_{30}\right)$ is positive and significant at the $5 \%$ significance level.

${ }^{14}$ A significant interaction effect (at the $1 \%$ significance level) was found between having little or no opportunities for advanced training and the age of participants (AGE) $\mathrm{x}\left(\mathrm{X}_{31}\right)$.
} 
that $\mathrm{X}_{33}$ was a "very important" or "important" push factor, which accounts for $85 \%$ of respondents in the sample. For those working in academic or research-oriented organizations, having no job opportunities in their specialization in Turkey increases the probability of not returning by 0.04 . Having no advanced training opportunities in Turkey $\left(\mathrm{X}_{31}\right)$ increases the probability of non-return by 0.03 for the average respondent ${ }^{15}$. However, this negative impact on return intentions is greater for older respondents as can be seen in Figure 6. In general, the probability of not returning (as indicated by responding 'yes' to either "definitely not return" or "return unlikely" category) increases with the age of the respondent. For those who consider lack of training opportunities in Turkey to be an important push factor, the probability of not returning increases at a faster rate then for those who do not consider it to be important. On the other hand, the probability of definitely returning increases by 0.03 for those indicating that the lack of business opportunities in Turkey $\left(\mathrm{X}_{32}\right)$ is an important push factor. This may be reflecting the fact that the percentage of non-academic respondents who indicated business opportunities in Turkey as an important factor is much greater than that of academics (33\% versus $22 \%$ ), who have a much higher non-return probability.

The number of significant pull factors is greater compared to the push factors. Eight of the twelve pull factors presented to participants are found to be statistically significant. Since respondents in the target group are residing outside Turkey, it is natural that factors in their immediate environment will have a greater impact on their current return intentions. Table 3 gives the marginal effects of the significant pull factors. The greatest negative impact on the probability of returning is from family considerations $\left(\mathrm{X}_{38}\right.$ and $\left.\mathrm{X}_{39}\right)$, but there are gender differences. Spouse's job or preference appears to play a greater role in the stay decision of males. Greater opportunities for developing specialty $\left(\mathrm{X}_{34}\right)$, a more satisfying social and cultural life $\left(\mathrm{X}_{36}\right)$, proximity to research centers $\left(\mathrm{X}_{37}\right)$ and a more organized, ordered environment $\left(\mathrm{X}_{35}\right)$ follow. The other two pull factors - the need to finish or complete an overseas project $\left(\mathrm{X}_{40}\right)$ and other reasons $\left(\mathrm{X}_{41}\right)$ for male respondents - are associated with positive return intentions. For males, the effect of "other" factors is mainly that of wanting to return to complete military service in Turkey.

\footnotetext{
${ }^{15}$ Richardson et al. (2006) report professional reasons, such as career opportunities and/or personal life, as the key driver in the decisions of US academics to migrate to Canada.
} 
16. Last Impressions $\left(X_{42}, X_{43}, X_{44}\right)$ : Return intentions may be shaped by the last impression from the latest trip to Turkey. In this section we consider the effect of the last visit made to Turkey on the return intentions of participants. A visit to Turkey made after a long period of time abroad may radically change an individual's perceptions about conditions in Turkey, either for the better or for the worse. Whatever the case, these personal observations lead to changes in the probability of returning. The probability of returning ( $y=1$ or 2$)$ decreases by about 0.04 for those who were negatively effected by their last trip to Turkey, and increases by 0.22 for those who were left with more positive impressions. From this, it appears that positive impressions appear to have a greater impact on the probability of returning.

The effect of the September 11, 2001 terrorist attacks in New York $\left(\mathrm{X}_{44}\right)$ is also considered. The effect, in general, is to increase return intentions since the coefficient on this variable is negative and statistically significant at the $5 \%$ level. The probability of returning (y $=1$ or 2 ) increases by 0.07 . For a small minority of respondents, Sept.11 had the opposite effect on return intentions but this is not statistically significant and is therefore excluded from the final model.

\section{Concluding Remarks}

In economic explanations of the brain drain, skilled migration is viewed as a response to the wage differentials that exist between the host and source countries. Wage differentials, however, provide only a partial explanation for why skilled migration from developing countries to developed countries exists. The ordered probit models estimated in the current study are based on the human capital theory of migration, which predicts that individuals will migrate when the net present value of benefits from migration is positive. The income differential, however, fails to be a discerning factor in distinguishing between respondents with strong return intentions versus those with weak return intentions, since a majority of respondents consider income to be important. While the importance of income differentials is emphasized in the literature, our study provides quantitative evidence on the importance of non-pecuniary factors, such as lifestyle and family considerations, including initial return intentions, family support to settle abroad, stay duration, work experience and specialized training abroad and other factors in the return versus non-return decision of the highly educated. 
The greatest positive impact on the probability of not returning occurs when the initial return intention is to stay compared to those who initially intended to return. Family considerations, such as family support for the decision to settle abroad, not surprisingly, have considerable weight in the mobility decisions of the survey participants, indicating that remaining abroad is not simply a matter of earning a higher salary or enjoying better work conditions. Marriage to a foreign spouse is obviously an important factor in not returning. For others, concern over children's adaptation to the highly competitive education system in Turkey may also dominate the return decision.

Female respondents appear less inclined to be returning to Turkey than male respondents. In our study, the parents of female survey participants were more educated than that of males. Since parental education is highly correlated with the socio-economic background of participants, this may be indicative of a more selective migration process working in the case of females. Some female participants have also indicated that they enjoy greater freedom in lifestyle choice abroad than they do in Turkey, which may also be an important factor in the non-return decision.

Stay duration, work experience in the host country and specialized training are all found to have significant negative impacts on the return intentions of Turkish professionals. In addition, work experience in Turkey after obtaining a PhD abroad substantially increases the likelihood of not returning. Those in academe are also less likely to be returning compared to those in other work environments. Among the push and pull factors cited as being important in the migration decision, economic instability has the greatest deterrent effect on return intentions. In general, our findings suggest that the return decision is based in part on initial plans that take into consideration both pecuniary and non-pecuniary aspects of migration.

\section{REFERENCES}

Adams, W. (1968) The Brain Drain, New York: Macmillan \& Co.

Agarwal, V. B. and D. R. Winkler (1984) "Migration of Professional Manpower to the United States." Southern Economic Journal 50: 814-830.

Agarwal, V. B. and D. R. Winkler (1985) "United States Immigration Policy and Indirect Immigration of Professionals." Economics of Education Review 4: 1-16.

Atkinson, R. and J. Flint (2001) "Accessing Hidden and Hard-to-Reach Populations: Snowball Research Strategies." Social Research Update Issue 33. Department of Sociology. UK: University of Surrey. <http://www.soc.surrey.ak.uk/sru/SRU33.html> 
Beine, M., F. Docquier and H. Rapoport (2001) "Brain Drain and Economic Growth: Theory and Evidence." Journal of Development Economics 64(1): 275-289.

Beine, M., F. Docquier and H. Rapoport (2003) "Brain Drain and LDC's Growth: Winners and Losers." IZA Discussion Paper No. 819, Bonn.

Beine, M., F. Docquier and H. Rapoport (2008) "Brain Drain and Economic Growth: Theory and Evidence." Journal of Development Economics 64(1): 275-289.

Bhagwati, J. N. and M. Partington (1976) Taxing the Brain Drain: A Proposal, Amsterdam: North-Holland.

Bollard, A., D. McKenzie, M. Morten and H. Rapoport (2009) "Remittances and the Brain Drain Revisited." Policy Research Working Paper No. 5113, Washington, D.C.: World Bank.

Bratsberg, B. (1995) "Incidence of Non-Return among Foreign Students in the United States." Economics of Education Review 14(4): 373-384.

Brzozowski, J. P. (2007) "Brain Waste, Educational Investments and Growth in Transitional Countries." Cracow University of Economics, European Studies Department, Working Paper, Krakow, Poland. <http://ssm.com/abstract=991785>

Bucovetsky, S. (2003) "Efficient Migration and Redistribution." Journal of Public Economics 87: 2459-2474.

Cassarino, J.-P. (2004) "Theorising Return Migration: The Conceptual Approach to Return Migrants Revisited.” International Journal of Multicultural Societies 6(2):253-279.

Checchi, D., G. D. Simone and R. Faini (2007) "Skilled Migration, FDI and Human Capital Investment." IZA Discussion Paper No. 2795, Bonn, Germany: IZA.

Chen, T.-J. and H.-Y. Su (1995) "On-the-job Training as a Cause of Brain Drain." Weltwirtschaftliches Archiv 131(3):526-41.

Cortés, C. (ed.) (1980) The Latin American Brain Drain to the United States, New York: Arno Press.

Dessy, S. and Rambeloma, T. (2009) "Immigration Policy, Remittances and Growth in the Migrant-Sending Country." Centie Interuniversitaire sur le Risque, les Politiques Economiques et l'Emploi (CIRPEE) Working Paper No. 09-15, Paris.

Docquier, F., Lowell, B. Lindsay and A. Marfouk (2007) "A Gendered Assessment of the Brain Drain.” IZA Discussion Paper No. 3235, Bonn, Germany: IZA.

Dumont, J.-C. and J. P. Martin and G. Spielvogel (2007) "Women on the Move: The Neglected Gender Dimension of the Brain Drain.” IZA Discussion Paper No. 2920, Bonn, Germany: IZA.

Dustmann, C. (2001) "Why Go Back? Return Motives of Migrant Workers.” in S. Djajic (ed.) International Migration: Trends, Policy and Economic Impacts, NY: Routledge.

Faini, R. (2003) "Is the Brain Drain an Unmitigated Blessing?" WIDER Discussion Paper No. 2003 / 64, Helsinki.

Faini, R. (2006) "Remittances and the Brain Drain.” IZA Discussion Paper No. 2155, Bonn, Germany: IZA.

Finn, M. G. (2001) "Stay Rates of Foreign Doctorate Recipients from US Universities, 1999" Oak Ridge, Tennessee: Oak Ridge Institute for Science and Education.

Finn, M. G. (2003) "Stay Rates of Foreign Doctorate Recipients from US Universities, 2001" Oak Ridge, Tennessee: Oak Ridge Institute for Science and Education.

Finn, M. G. (2005) "Stay Rates of Foreign Doctorate Recipients from US Universities, 2003" Oak Ridge, Tennessee: Oak Ridge Institute for Science and Education.

Finn, M. G. (2007) "Stay Rates of Foreign Doctorate Recipients from US Universities, 2005" Oak Ridge, Tennessee: Oak Ridge Institute for Science and Education

Finn, M. G. (2010) "Stay Rates of Foreign Doctorate Recipients from US Universities, 2007" Oak Ridge, Tennessee: Oak Ridge Institute for Science and Education 
Globerman, S. and D. Shapiro (2006) "The International Mobility of Highly Educated Workers among OECD Countries.” Industry Canada Skills Research Initiative Working Paper 2006D-12. Ottawa, Canada: Industry Canada.

Glytsos, N. (2009) "Theoretical Considerations and Empirical Evidence on Brain Drain Grounding the Review of Albania's and Bulgaria's Experience." International Migration, online version, forthcoming in 2010.

Goss, E. P. and C. Paul (1985) "Age and Work Experience in the Decision to Migrate." The Journal of Human Resources 21(3): 397-405.

Gökbayrak, Ş. (2009) "Skilled Labour Migration and Positive Externality: The Case of Turkish Engineers Working Abroad." International Migration, online version, forthcoming in 2010.

Güngör, N. D. (2003) Brain Drain from Turkey: An Empirical Investigation of the Determinants of Skilled Migration and Student Non-Return, Unpublished PhD thesis. Ankara: Institute of Social Sciences, Middle East Technical University.

Güngör, N. D. and Tansel, A. (2008a) "Brain Drain from Turkey: An Investigation of Students' Return Intentions.” Applied Economics 40: 3069-3087.

Güngör, N. D. and Tansel, A. (2008b) "Brain Drain from Turkey: The Case of Professionals Abroad." International Journal of Manpower 29(4): 323-347.

Goss, E. P. and C. Paul (1986) "Age and Work Experience in the Decision to Migrate." The Journal of Human Resources 21(3):397-405.

Haque, U. N. (2005) "Brain Drain or Human Capital Flight." Lectures in Development Economics, No.11, Islamabad, Pakistan: Pakistan Institute of Development Economics.

Huang, W. C. (1987) "A Pooled Cross-Section and Times Series Study of Professional Indirect Immigration to the United States." Southern Economic Journal 54: 95-109.

Huang, W. C. (1988) "An Empirical Analysis of Foreign Student Brain Drain to the United States." Economics of Education Review 7: 231-243.

IIE (2001) Open Doors 2001: Report on International Educational Exchange, NY, New York: Institute of International Education.

IIE (2006) Open Doors 2006: Report on International Educational Exchange 20005/06, NY, New York: Institute of International Education <http://opendoors.iienetwork.org>

Işığıçok, Ö. (2002) “Türkiye'de yaşanan son ekonomik krizlerin sosyo-ekonomik sonuçları: Kriz işsizliği ve beyin göçü." (The socioeconomic results of the last two economic crises in Turkey: Crisis unemployment and brain drain) $<$ www.isguc.org/calhay_beyingocu.php $>$

Kao, C. and J. W. Lee (1973) "An Empirical Analysis of China's Brain Drain to the United States." Economic Development and Cultural Change 21(3):500-13.

Kapur, D. and J. McHale (2005) Give Us Your Best and Brightest: The Global Hunt for Talent and Its Impact on the Developing World, Washington, DC: Center for Global Development.

Kuhn, P. and C. McAusland (2006) "The International Migration of Knowledge Workers: When is Brain Drain Beneficial?" IZA Discussion Paper No. 2493, Bonn, Germany: IZA.

Kurtuluş, B. (1999) Amerika Birleşik Devletleri’ne Türk Beyin Göçü, (Turkish Brain Drain to the United States) İstanbul: Alfa Basım Yayım Dağıtım.

Liu-Farrer, G. (2009) "Educationally Channeled International Labor Mobility: Contemporary Student Migration from China to Japan.” International Migration Review 43(1):178204.

Long, J. S. and J. Freese (2001) Regression Models for Categorical Dependent Variables Using Stata, College Station, TX: Stata Press. 
Maddala, G. S. (1983) Limited-Dependent and Qualitative Variables in Econometrics, Econometric Society Monographs, Cambridge: Cambridge University Press.

Mountford, A. (1997) "Can a Brain Drain be Good for Growth in the Source Economy?" Journal of Development Economics 53:287-303.

Niland, J. R. (1970) The Asian Engineering Brain Drain: A Study of International Relocation into the United States from India, China, Korea, Thailand and Japan, Lexington, Massachusetts: D. C. Heath and Company.

National Science Board (2006) Science and Engineering Indicators 2006, Two volumes. (volume 1, NSB 06-01; volume 2, NSB 06-01A). Arlington, VA: National Science Foundation.

NSF (1997) Survey of Doctorate Recipients. Division of Science Resources Studies, Arlington, VA: National Science Foundation.

OECD (1994) Proposed Standard Practice for Surveys of Research and Experimental Development: "Frascati Manual 1993", The Measurement of Scientific and Technological Activities Series, Paris: Organization for Economic Co-operation and Development.

Oğuzkan, T. (1971) Yurt Dışında Çalışan Doktoralı Türkler: Türkiye'den Başka Ülkelere Yüksek Seviyede Eleman Göçü Üzerinde Bir Araştırma, (Turks with Doctorate Degrees Working Abroad: An Investigation of the Migration of Highly Skilled Workers from Turkey to Other Countries) Ankara: Orta Doğu Teknik Üniversitesi.

Oğuzkan, T. (1975) "The Turkish Brain Drain: Migration of Tendencies among Doctoral Level Manpower." in R. E. Krane (ed.) Manpower Mobility Across Cultural Boundaries: Social, Economic and Legal Aspects, The Case of Turkey and West Germany, Leiden, Netherlands: E. J. Brill.

Özden, Ç. and M. Schiff (eds.) (2005) International Migration, Remittances and the Brain Drain, World Bank Publications, Washington DC: The World Bank and Palgrave MacMillan.

Rea, L. M. and R. A. Parker (1997) Designing and Conducting Survey Research: A Comprehensive Guide, Second Edition. San Francisco: Jossey-Bass Publishers.

Richardson, J. , K. Mc Bey and S. Mc Kenna (2006) "International Faculty in Canada: An Exploratory Study." Micro Economic Policy and Analyses Industry Working Paper No. 2006 D-22, Ottawa: Social Sciences and Humanities Research Council.

Schiff, M. (2005) "Brain Gain: Claims about its Size and Impact on Welfare and Growth are Greatly Exaggerated." In International Migration Remittances and the Brain Drain, Washington, D.C: The World Bank and Palgrave MacMillan (pp. 201-226).

Stark, O. and D. E. Bloom (1985) "The New Economics of Labor Migration." American Economic Review, Papers and Proceedings 75(2):173-178.

Stark, O., C. Helmenstein and A. Prskawetz (1997) "A Brain Gain with a Brain Drain." Economics Letters 55:227-234.

Stark, O., C. Helmenstein and A. Prskawetz (1998) "Human Capital Depletion, Human Capital Formation and Migration: A Blessing or a Cure?" Economics Letters 60(3):363367.

Tansel, A. and N. D. Güngör, N.D. (2003) “"Brain Drain’ from Turkey: Survey Evidence of Student Non-Return." Special issue on Career Development in the Middle East. Career Development International 8(2):52-69.

Wong, K. (1995) "International Labor Migration." In International Trade in Goods and Factor Mobility, Cambridge, MA: The MIT Press.

Zweig, D. and C. Changgui (1995) China's Brain Drain to the United States: Views of Overseas Chinese Students and Scholars in the 1990s, China Research Monograph. Berkeley, CA: Institute of East Asian Studies, University of California. 
TABLE 1

STAY RATES FOR TURKISH SCIENCE/ENGINEERING PHD RECIPIENTS IN THE UNITED STATES

\begin{tabular}{lccc}
\hline Year Received & Number of Recipients & 5-Year Stay Rate & 1-Year Stay Rate \\
\hline $1994 / 1995$ & 252 & 44 (in 1999) & 46 (in 1996) \\
1996 & 124 & $50($ in 2001) & 57 (in 1997) \\
1998 & 153 & $48($ in 2003) & 52 (in 1999) \\
2000 & 248 & $49($ in 2005) & $52($ in 2001) \\
2002 & 315 & $42($ in 2007) & 53 (in 2003) \\
\hline
\end{tabular}

Note: The five-year stay rate gives the percent of those still in the US five years after receipt of PhD degree Similarly, the one-year stay rate gives the percent of those still in the US one year after receipt of PhD degree. The figures include only those students on temporary visas.

Source: Finn (2001, 2003, 2005, 2007, 2010).

TABLE 2

DEPENDENT VARIABLE, RETURN INTENTIONS

\begin{tabular}{llc}
\hline Response Categories & Label & Index (y) \\
\hline Professionals & & \\
I will definitely return and have made plans to do so. & $D R P$ & 1 \\
I will definitely return but have not made concrete plans to do so. & $D R N P$ & 2 \\
I will probably return. & $R P$ & 3 \\
I don't think that I will be returning. & $R U$ & 4 \\
I will definitely not return. & $D N R$ & 5 \\
\hline
\end{tabular}


TABLE 3

ORDERED PROBIT MODEL OF RETURN INTENTIONS

Regressors (X)

Demographic Characteristics:

$\mathrm{X}_{1}$ : Gender (1=female) (FEMALE)

$\mathrm{X}_{2}$ : Age of respondent in 2001 (years) (AGE)

$\mathrm{X}_{3}$ : Square of age (AGESQ)

$\mathrm{X}_{4}$ : Stay duration of respondent (years) (STAY DURATION)

Initial Return Intentions: (1=yes)

$\mathrm{X}_{5}$ : Initial return intention is "unsure"

$\mathrm{X}_{6}$ : Initial return intention is "return"

Family Support: (1=yes)

$\mathrm{X}_{7}$ : Family support initial decision to go abroad

$\mathrm{X}_{8}$ : Family support settling abroad

$\mathrm{X}_{9}$ : Married to a foreign spouse

Characteristics of Highest Degree ( $1=y e s)$ :

$\mathrm{X}_{10}$ : Highest degree is obtained from a Turkish university

$\mathrm{X}_{11}$ : Field of highest degree: Education/Languages/Social

Sciences/Arts

(base: Architecture/Economics/Admin.Sciences)

$\mathrm{X}_{12}$ : Field of highest degree:

Engineering/Maths/Sciences/Medicine

(base: Architecture/Economics/Admin.Sciences)

Work Experience: (1=yes)

$\mathrm{X}_{13}$ : Work experience in current country (years)

$\mathrm{X}_{14}$ : No work experience in Turkey

$\mathrm{X}_{15}$ : Worked in Turkey after completing studies

$\mathrm{X}_{16}$ : Received formal training abroad specific to organization

$\mathrm{X}_{17}$ : Currently working in an academic environment

(university, research center) (ACADEMIC)

Assessment of Life Abroad:

$\mathrm{X}_{18}$ : Social life in host country (five point scale)

$\mathrm{X}_{19}$ : Standard of living in host country (five point scale)

Reasons for Going Abroad: (1=yes)

$\mathrm{X}_{20}$ : Job requirement in Turkey

$\mathrm{X}_{21}$ : Insufficient research facilities in Turkey

$\mathrm{X}_{22}$ : Prestige of international study

$\mathrm{X}_{23}$ : Lifestyle preference

$\mathrm{X}_{24}$ : Spouse / family considerations

$\mathrm{X}_{25}$ : Political environment in Turkey

Factors Relating to Adjustment to Life Abroad: (1=yes)

$\mathrm{X}_{26}$ : Previous overseas experience

$\mathrm{X}_{27}$ : Support of Turkish Student Association

$\mathrm{X}_{28}$ : Being away from family is viewed to be an important difficulty in living abroad $\beta$

z-statistic $^{\mathrm{a}} \quad \mathrm{MEAN}(\mathrm{X}) \mathrm{SD}(\mathrm{X})$

$\begin{array}{rlrr}0.355 & (2.40)^{* *} & 0.28 & 0.45 \\ 0.085 & (1.11) & 35.04 & 8.90 \\ -0.001 & (0.54)^{* * *} & 1307.99 & 722.14 \\ 0.327 & (3.40)^{* *} & 12.78 & 6.89 \\ & & & \\ & & & \\ -0.950 & (6.65)^{* * *} & 0.36 & 0.48 \\ -1.323 & (8.87)^{* * *} & 0.53 & 0.50\end{array}$

$-0.176$

$(2.82)^{* * *}$

3.48

0.75

0.154

$(5.46)^{* * *}$

4.39

1.51

0.403

$(3.43)^{* * *}$

0.15

0.36

$-0.477$

$(2.31)^{* *}$

0.04

0.20

0.544

$(3.03)^{* * *}$

0.04

0.20

0.270

$(3.29)^{* * *}$

0.66

0.47

0.051

0.213

$(3.23)^{* * *}$

6.84

0.32

6.88

0.475

$(2.45)^{*}$

$(3.18)^{* * *}$

0.09

0.47

0.366

(1.90) ${ }^{*}$

0.04

0.29

0.078

(0.39)

0.27

0.44

0.101

$(2.43)^{* *}$

2.63

1.00

0.129

$(2.80)^{* * *}$

4.48

0.81

$-0.190$

$(1.92)^{*}$

$(4.22)^{* * *}$

0.22

0.27

0.42

1.536

$(1.69)^{*}$

0.178

$(2.14)^{* *}$

0.46

0.44

0.50

$-0.454$

$(2.95)^{* * *}$

0.33

0.47

0.144

(1.69) ${ }^{*}$

0.12

0.33

0.32

0.47

$-0.268$

$(3.58)^{* * *}$

0.43

0.50

$-0.248$

(1.51)

0.05

0.21

$-0.217$

$(2.21)^{* *}$

0.83

0.38 
Contributions to Turkey: (1=yes)

$\mathrm{X}_{29}$ : Contributed to lobbying activities on behalf of Turkey

Push Factors for Going Abroad (1=yes):

$\mathrm{X}_{30}$ : Limited job opportunity in specialty at home

$\mathrm{X}_{32}$ : Lack of financial resources for business at home

$\mathrm{X}_{33}$ : Economic instability at home

Pull factors for Going Abroad (1=yes):

$\mathrm{X}_{34}$ : Greater opportunity to develop specialty abroad

$\mathrm{X}_{35}$ : More organized, ordered environment abroad

$\mathrm{X}_{36}$ : More satisfying social and cultural life abroad

$\mathrm{X}_{37}$ : Proximity to research and innovation centers abroad

$\mathrm{X}_{38}$ : Spouse's preference or job

$\mathrm{X}_{39}$ : Better educational opportunities for children abroad

$\mathrm{X}_{40}$ : Incomplete project abroad

$\mathrm{X}_{41}$ : Other considerations

Last Impressions $(1=y e s)$ :

$\mathrm{X}_{42}$ : Last visit to Turkey left negative impression

$\mathrm{X}_{43}$ : Last visit to Turkey left positive impression

$\mathrm{X}_{44}$ : Effect of Sept. 11, 2001 terrorist attacks

Variable Interactions:

(AGE) x (STAY DURATION)

(AGESQ) x (STAY DURATION)

(FEMALE) $\mathrm{x}\left(\mathrm{X}_{20}\right)$

(FEMALE) $\mathrm{x}\left(\mathrm{X}_{24}\right)$

(ACADEMIC) $\mathrm{x}\left(\mathrm{X}_{22}\right)$

(AGE) $\mathrm{x}\left(\mathrm{X}_{21}\right)$

(AGE) $\mathrm{x}\left(\mathrm{X}_{22}\right)$

(FEMALE) $\mathrm{x}\left(\mathrm{X}_{30}\right)$

(FEMALE) $\mathrm{x}\left(\mathrm{X}_{38}\right)$

(FEMALE) $\mathrm{x}\left(\mathrm{X}_{40}\right)$

(FEMALE) $\mathrm{x}\left(\mathrm{X}_{41}\right)$

(ACADEMIC) $x\left(\mathrm{X}_{30}\right)$

(ACADEMIC) $x\left(\mathrm{X}_{34}\right)$

$(\mathrm{ACADEMIC}) \times\left(\mathrm{X}_{37}\right)$

(AGE) $\mathrm{x}\left(\mathrm{X}_{31}\right)$
$-0.070$

$-0.966$

$-0.132$

$\begin{array}{lll}(0.69)^{* *} & 0.54 & 0.50 \\ (2.96)^{* * *} & 0.37 & 0.48 \\ (1.65)^{*} & 0.30 & 0.46 \\ (3.38)^{* * *} & 0.85 & 0.35\end{array}$

0.263

$(2.59)^{* * *}$

0.71

0.45

0.164

$(1.76)^{* *}$

0.77

0.42

0.275

$(3.05)^{* * *}$

0.26

0.44

$-0.215$

$(2.10)^{* *}$

$(3.58)^{* * *}$

0.42

0.49

0.31

0.46

0.317

$(3.67)^{* * *}$

0.37

0.48

$(4.99)^{* * *}$

0.16

0.36

$-0.460$

$(2.12)^{* *}$

0.05

0.21

0.154

$(1.87)^{*}$

0.28

0.45

$-0.716$

$(5.64)^{* * *}$

0.09

0.29

$-0.262$

$(2.06)^{* *}$

0.10

0.30

Notes: Dependent variable (y) = return intentions in five categories (see Table 2);

* significant at $10 \%$; * significant at $5 \%$; *** significant at $1 \%$;

$\beta=$ estimated coefficient; MEAN $(X)=$ mean value of independent variable; $\mathrm{SD}(\mathrm{X})=$ standard deviation of independent variable; (a) Robust z-statistics in parentheses; Observations $=960 ;$ Log-likelihood $=-1073.44 ; \mathrm{LR} \mathrm{chi}^{2}(48)=583.83$;

Maximum Likelihood $\mathrm{R}^{2}=0.491$; McFadden's Adjusted $\mathrm{R}^{2}=0.194$; McKelvey-Zavoina $\mathrm{R}^{2}=0.535$; Akaike Information Criterion $(\mathrm{AIC})=2.347$; Bayesian Information Criterion $(\mathrm{BIC})=-4081.431$. 
TABLE 4

MARGINAL EFFECTS OF SELECTED VARIABLES IN THE ORDERED PROBIT MODEL OF RETURN INTENTIONS (CHANGE IN PROBABILITY)

\begin{tabular}{|c|c|c|c|c|c|}
\hline \multirow[b]{2}{*}{ VARIABLES } & \multicolumn{5}{|c|}{ Intensity of Return Intentions } \\
\hline & $\begin{array}{c}\text { DRP } \\
\mathrm{y}=1 \\
\text { (high) }\end{array}$ & $\begin{array}{c}\text { DRNP } \\
\mathrm{y}=2\end{array}$ & $\begin{array}{c}\text { RP } \\
y=3\end{array}$ & $\begin{array}{c}\mathrm{RU} \\
\mathrm{y}=4\end{array}$ & $\begin{array}{l}\text { DNR } \\
\mathrm{y}=5 \\
\text { (low) }\end{array}$ \\
\hline \multicolumn{6}{|l|}{ Discrete Variables: } \\
\hline Female $\left(\mathrm{X}_{1}\right)$ & -0.0027 & -0.0646 & -0.0413 & 0.0998 & 0.0088 \\
\hline \multicolumn{6}{|l|}{ Initial Return Intentions: } \\
\hline "Undecided" $\left(\mathrm{X}_{5}\right)$ (compared to base category "stay") & 0.0025 & 0.1161 & 0.2436 & -0.2775 & -0.0846 \\
\hline "Return" $\left(\mathrm{X}_{6}\right)$ (compared to "undecided" $\left(\mathrm{X}_{5}\right)$ ) & 0.0052 & 0.0946 & 0.0292 & -0.1212 & -0.0078 \\
\hline "Return" $\left(\mathrm{X}_{5}\right)$ (compared to base category "stay") & 0.0077 & 0.2107 & 0.2728 & -0.3987 & -0.0924 \\
\hline Married to foreign spouse $\left(\mathrm{X}_{9}\right)$ & -0.0030 & -0.0823 & -0.0673 & 0.1383 & 0.0145 \\
\hline Highest degree is from a Turkish University $\left(\mathrm{X}_{10}\right)$ & 0.0093 & 0.1320 & 0.0113 & -0.1451 & -0.0075 \\
\hline \multicolumn{6}{|l|}{ Highest Degree Field: } \\
\hline $\begin{array}{l}\text { Sciences / Arts }\left(\mathrm{X}_{11}\right) \text { compared to base } \\
\mathrm{X}_{11} \text { compared to Highest degree in Engineering / Maths / }\end{array}$ & -0.0051 & -0.1193 & -0.0764 & 0.1836 & 0.0172 \\
\hline $\begin{array}{l}\text { Sciences / Medicine }\left(\mathrm{X}_{12}\right) \\
\text { Highest Degree in Architecture / Economics / }\end{array}$ & -0.0034 & -0.0670 & -0.0240 & 0.0886 & 0.0060 \\
\hline Admin.Sciences (Base) compared to $\mathrm{X}_{12}$ & 0.0017 & 0.0523 & 0.0524 & -0.0950 & -0.0112 \\
\hline No Work Experience in Turkey $\left(\mathrm{X}_{14}\right)$ & -0.0020 & -0.0482 & -0.0280 & 0.0722 & 0.0060 \\
\hline MALE & -0.0026 & -0.0519 & -0.0210 & 0.0705 & 0.0049 \\
\hline FEMALE & -0.0012 & -0.0385 & -0.0436 & 0.0737 & 0.0095 \\
\hline Worked in Turkey after completing studies $\left(\mathrm{X}_{15}\right)$ & -0.0031 & -0.0919 & -0.0873 & 0.1630 & 0.0194 \\
\hline MALE & -0.0039 & -0.1001 & -0.0741 & 0.1620 & 0.0162 \\
\hline FEMALE & -0.0017 & -0.0711 & -0.1149 & 0.1581 & 0.0295 \\
\hline Received formal training abroad specific to organization $\left(\mathrm{X}_{16}\right)$ & -0.0025 & -0.0726 & -0.0651 & 0.1261 & 0.0139 \\
\hline Working in an academic environment $\left(\mathrm{X}_{17}\right)$ & -0.0021 & -0.0510 & -0.0329 & 0.0790 & 0.0070 \\
\hline \multicolumn{6}{|l|}{ Reasons for Going Abroad: } \\
\hline Job requirement in Turkey $\left(\mathrm{X}_{20}\right)$ & 0.0011 & 0.0224 & 0.0100 & -0.0313 & -0.0023 \\
\hline Insufficient research facilities in Turkey $\left(\mathrm{X}_{21}\right)$ & -0.0008 & -0.0183 & -0.0106 & 0.0274 & 0.0023 \\
\hline Prestige of international study $\left(\mathrm{X}_{22}\right)$ & 0.0005 & 0.0119 & 0.0065 & -0.0175 & -0.0013 \\
\hline Lifestyle preference $\left(\mathrm{X}_{23}\right)$ & -0.0018 & -0.0407 & -0.0228 & 0.0605 & 0.0049 \\
\hline Spouse / family considerations $\left(\mathrm{X}_{24}\right)$ & 0.0054 & 0.0905 & 0.0196 & -0.1092 & -0.0064 \\
\hline Political environment in Turkey $\left(\mathrm{X}_{25}\right)$ & -0.0014 & -0.0331 & -0.0183 & 0.0489 & 0.0039 \\
\hline \multicolumn{6}{|l|}{ Factors Relating to Adjustment Abroad: } \\
\hline Previous overseas experience $\left(\mathrm{X}_{26}\right)$ & 0.0030 & 0.0640 & 0.0292 & -0.0897 & -0.0066 \\
\hline $\begin{array}{l}\text { Support of Turkish Student Association }\left(\mathrm{X}_{27}\right) \\
\text { Being away from family is viewed to be an important }\end{array}$ & 0.0036 & 0.0640 & 0.0174 & -0.0800 & -0.0049 \\
\hline difficulty in living abroad $\left(\mathrm{X}_{28}\right)$ & 0.0019 & 0.0475 & 0.0312 & -0.0741 & -0.0066 \\
\hline $\begin{array}{l}\text { Contributions to Turkey: } \\
\text { Contributed to lobbying activities on behalf of Turkey } \\
\left(\mathrm{X}_{29}\right)\end{array}$ & 0.0039 & 0.0881 & 0.0508 & -0.1315 & -0.0112 \\
\hline \multicolumn{6}{|l|}{ Push Factors: } \\
\hline Limited job opportunity in specialty at home $\left(\mathrm{X}_{30}\right)$ & -0.0005 & -0.0188 & -0.0228 & 0.0371 & 0.0050 \\
\hline No opportunity for advanced training at home $\left(\mathrm{X}_{31}\right)$ & -0.0006 & -0.0159 & -0.0088 & 0.0234 & 0.0019 \\
\hline
\end{tabular}


Lack of financial resources for business at home $\left(\mathrm{X}_{32}\right)$

Economic instability at home $\left(\mathrm{X}_{33}\right)$

$\begin{array}{rrrrr}0.0015 & 0.0318 & 0.0140 & -0.0441 & -0.0032 \\ -0.0056 & -0.0961 & -0.0228 & 0.1174 & 0.0071 \\ & & & & \\ -0.0033 & -0.0648 & -0.0246 & 0.0867 & 0.0059 \\ -0.0020 & -0.0399 & -0.0162 & 0.0542 & 0.0038 \\ -0.0024 & -0.0605 & -0.0390 & 0.0937 & 0.0083 \\ -0.0017 & -0.0530 & -0.0532 & 0.0965 & 0.0115 \\ -0.0033 & -0.0786 & -0.0504 & 0.1215 & 0.0109 \\ -0.0031 & -0.0716 & -0.0417 & 0.1073 & 0.0090 \\ 0.0123 & 0.1694 & 0.0159 & -0.1873 & -0.0102 \\ 0.0106 & 0.1328 & -0.0032 & -0.1341 & -0.0060 \\ & & & & \\ -0.0015 & -0.0350 & -0.0200 & 0.0522 & 0.0043 \\ 0.0175 & 0.2044 & -0.0054 & -0.2065 & -0.0099 \\ 0.0037 & 0.0671 & 0.0191 & -0.0847 & -0.0053\end{array}$

Pull Factors:

Greater opportunity to develop specialty abroad $\left(\mathrm{X}_{34}\right)$

More organized, ordered environment abroad $\left(\mathrm{X}_{35}\right)$

More satisfying social and cultural life abroad $\left(\mathrm{X}_{36}\right)$

Proximity to research and innovation centers abroad $\left(\mathrm{X}_{37}\right)$

Spouse's preference or job $\left(\mathrm{X}_{38}\right)$

Better educational opportunities for children abroad $\left(\mathrm{X}_{39}\right)$

Incomplete project abroad $\left(\mathrm{X}_{40}\right)$

Other considerations $\left(\mathrm{X}_{41}\right)$

Last Impressions:

Last visit to Turkey left negative impression $\left(\mathrm{X}_{42}\right)$

Last visit to Turkey left positive impression $\left(\mathrm{X}_{43}\right)$

Effect of Sept. 11, 2001 terrorist attacks $\left(\mathrm{X}_{44}\right)$

Notes: DRP: Definitely Return, Plans; DRNP: Definitely Return, No Plans; RP: Return Probable; RU: Return Unlikely;

DNR: Definitely Not Return 
TABLE 5

MARGINAL EFFECTS OF SELECTED VARIABLES IN THE

ORDERED PROBIT MODEL OF RETURN INTENTIONS (CONTINUOUS VARIABLES)

\begin{tabular}{|c|c|c|c|c|c|}
\hline \multirow[b]{2}{*}{ Probabilities: } & \multicolumn{5}{|c|}{ Intensity of Return Intentions } \\
\hline & $\begin{array}{l}\text { DRP } \\
y=1\end{array}$ & $\begin{array}{c}\text { DRNP } \\
\mathrm{y}=2\end{array}$ & $\begin{array}{c}R P \\
y=3\end{array}$ & $\begin{array}{c}\mathrm{RU} \\
\mathrm{y}=4\end{array}$ & $\begin{array}{l}\text { DNR } \\
y=5\end{array}$ \\
\hline Initial family support $\left(\mathbf{X}_{7}\right)$ & $\begin{array}{l}0.0019 \\
(2.21)^{* *}\end{array}$ & $\begin{array}{c}0.0413 \\
(2.79)^{* * *}\end{array}$ & $\begin{array}{l}0.0206 \\
(2.61)^{* * *}\end{array}$ & $\begin{array}{l}-0.0593 \\
(-2.82)^{* * *}\end{array}$ & $\begin{array}{l}-0.0045 \\
(-2.31)^{* *}\end{array}$ \\
\hline $\begin{array}{l}\text { Family support for permanent } \\
\text { settlement abroad }\left(X_{8}\right)\end{array}$ & $\begin{array}{l}-0.0016 \\
(-3.11)^{* * *}\end{array}$ & $\begin{array}{l}-0.0362 \\
(-5.28)^{* * *}\end{array}$ & $\begin{array}{l}-0.0181 \\
(-4.25)^{* * *}\end{array}$ & $\begin{array}{l}0.0520 \\
(5.43)^{* * *}\end{array}$ & $\begin{array}{l}0.0039 \\
(3.49)^{* *}\end{array}$ \\
\hline Social Assessment $\left(X_{18}\right)$ & $\begin{array}{l}-0.0011 \\
(-2.09)^{* *}\end{array}$ & $\begin{array}{l}-0.0237 \\
(-2.42)^{* *}\end{array}$ & $\begin{array}{l}-0.0118 \\
(-2.29)^{* *}\end{array}$ & $\begin{array}{l}0.0340 \\
(2.42)^{* *}\end{array}$ & $\begin{array}{l}0.0026 \\
(2.25)^{* *}\end{array}$ \\
\hline $\begin{array}{l}\text { Standard of Living Assessment } \\
\left(X_{19}\right)\end{array}$ & $\begin{array}{l}-0.0014 \\
(-2.21)^{* *}\end{array}$ & $\begin{array}{l}-0.0304 \\
(-2.78)^{* * *}\end{array}$ & $\begin{array}{l}-0.0152 \\
(-2.57)^{* * *}\end{array}$ & $\begin{array}{l}0.0436 \\
(2.79)^{* * *}\end{array}$ & $\begin{array}{l}0.0033 \\
(2.36)^{* *}\end{array}$ \\
\hline
\end{tabular}

Notes: Figures in parentheses are z-statistics.

DRP: Definitely Return, Plans; DRNP: Definitely Return, No Plans; RP: Return Probable;

RU: Return Unlikely; DNR: Definitely Not Return 
Figure 1

Effects of Stay Duration on Return Intention Probabilities (Age $=35$ years)

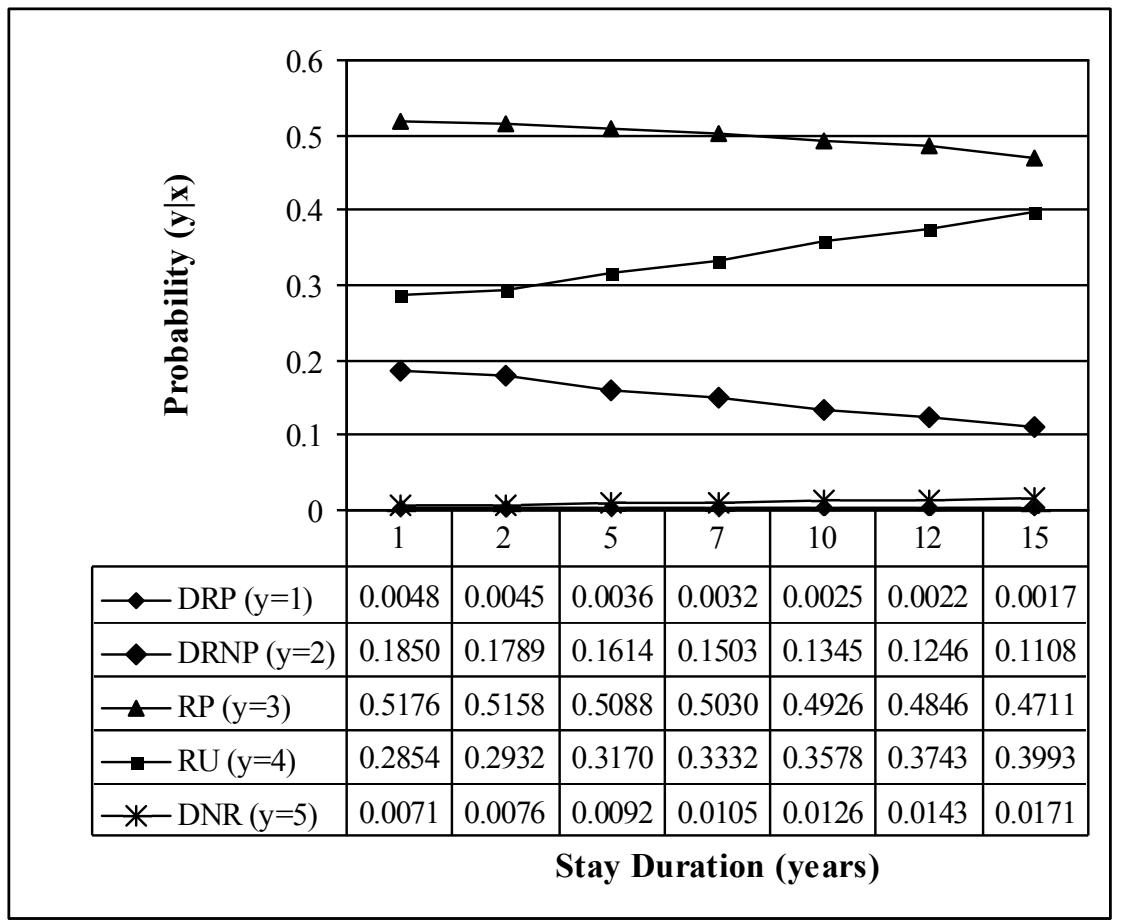

Notes:1) DRP: Definitely Return, Plans; DRNP: Definitely Return, No Plans; RP: Return Probable; RU: Return Unlikely; DNR: Definitely Not Return

2) The probabilities are computed for an individual of age 35 while all other variables are set at their sample averages. 
Figure 2

Stay Duration and Cumulative Probabilities of Return Intentions

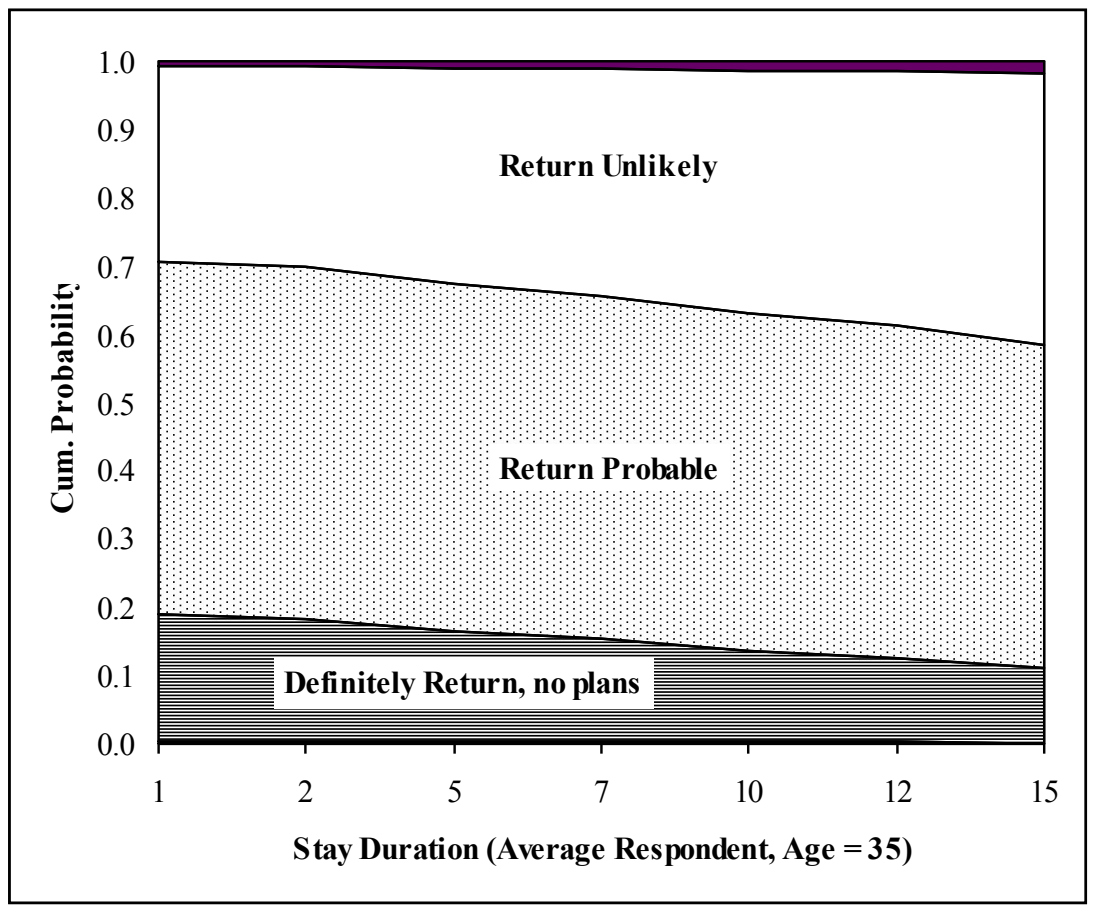


Figure 3

Effect of Work Experience in Current Country on Return Intention Probabilities

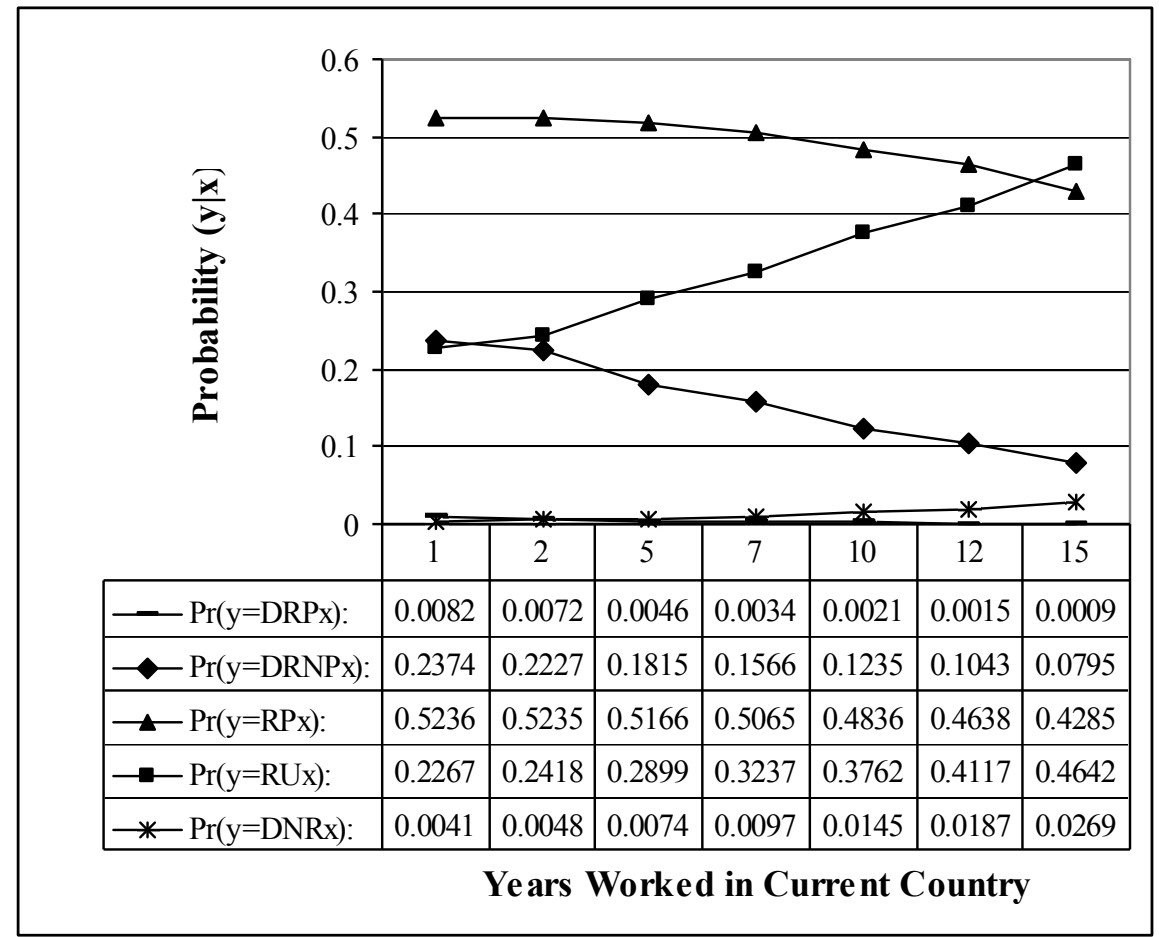

Notes: DRP: Definitely Return, Plans; DRNP: Definitely Return, No Plans; RP: Return Probable; RU: Return Unlikely; DNR: Definitely Not Return 
Figure 4

Cumulative Probabilities of Social Assessment of Life Abroad

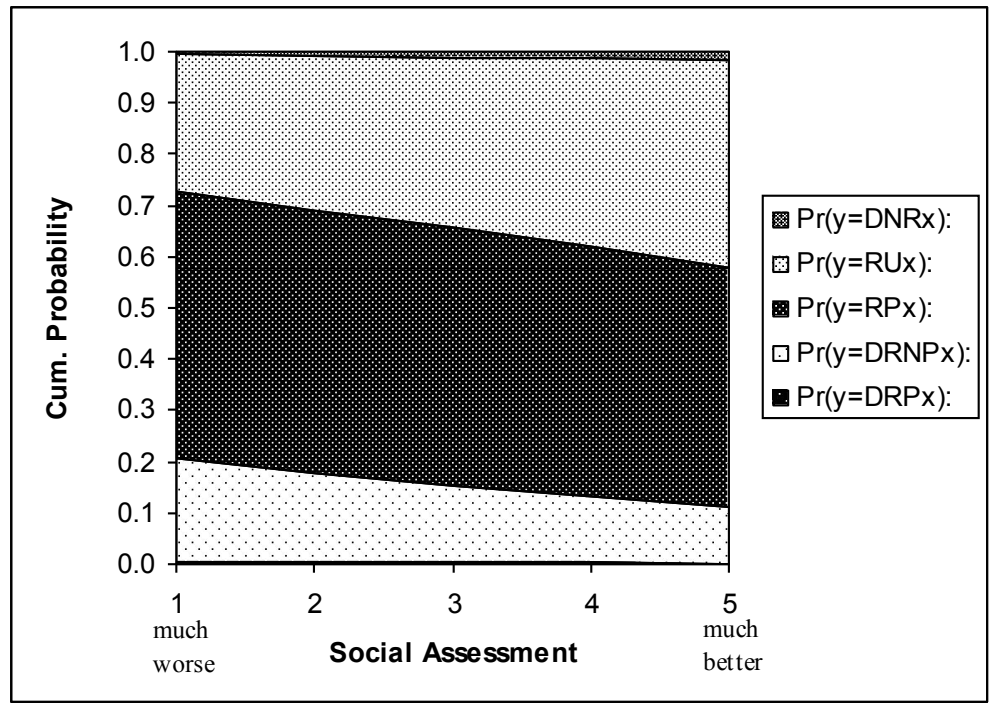

Notes: DRP: Definitely Return, Plans; DRNP: Definitely Return, No Plans; RP: Return Probable; RU: Return Unlikely; DNR: Definitely Not Return 
Figure 5

Cumulative Probabilities of Standard of Living Assessment of Life Abroad

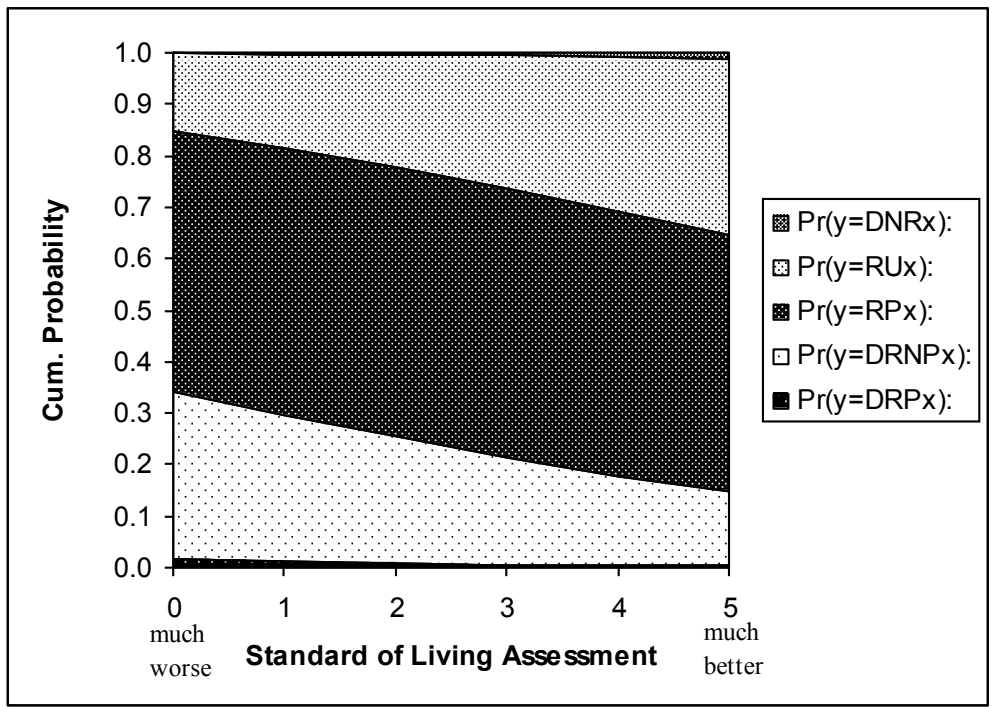

Notes: DRP: Definitely Return, Plans; DRNP: Definitely Return, No Plans; RP: Return Probable; RU: Return Unlikely; DNR: Definitely Not Return 
Figure 6

Effect of the Interaction between Age and Lack of Advanced Training Opportunities in Turkey on the Probability of Not Returning $(y=4$ or 5$)$

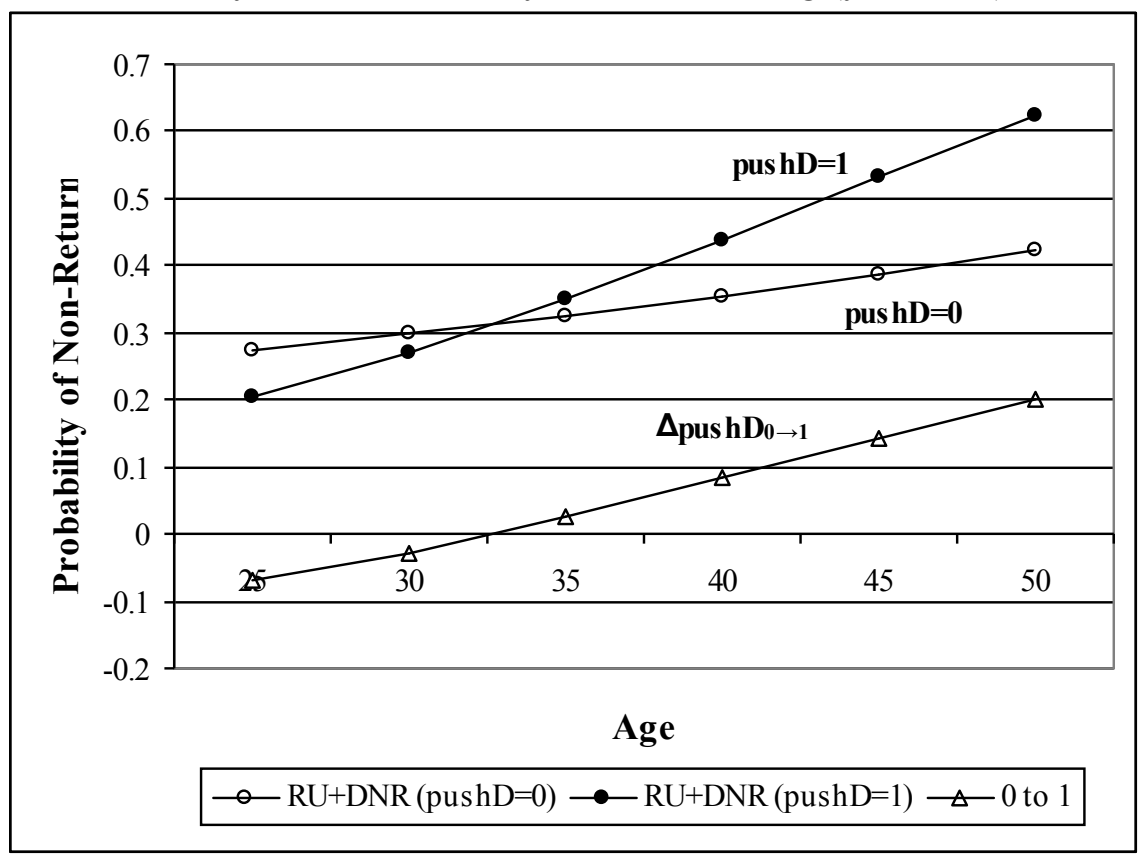

Notes: RU: Return Unlikely; DNR: Definitely Not Return 